\title{
A Novel Multisensory Integration Task Reveals Robust Deficits in Rodent Models of Schizophrenia: Converging Evidence for Remediation via Nicotinic Receptor Stimulation of Inhibitory Transmission in the Prefrontal Cortex
}

\author{
Jacob M. Cloke, ${ }^{1,2}$ Robin Nguyen, ${ }^{4}$ Beryl Y.T. Chung, ${ }^{2,3}$ David I. Wasserman, ${ }^{1}$ Stephanie De Lisio, ${ }^{1}$ Jun Chul Kim, ${ }^{4}$ \\ (CCraig D.C. Bailey, ${ }^{2,3}$ and Boyer D. Winters ${ }^{1,2}$ \\ 'Department of Psychology, ${ }^{2}$ Collabrative Neuroscience Program, and ${ }^{3}$ Department of Biomedical Sciences, Ontario Veterinary College, University of \\ Guelph, Guelph, Ontario, Canada N1G 2W1, and ${ }^{4}$ Department of Psychology, University of Toronto, Toronto, Ontario, Canada M5S 3GS
}

Atypical multisensory integration is an understudied cognitive symptom in schizophrenia. Procedures to evaluate multisensory integration in rodent models are lacking. We developed a novel multisensory object oddity (MSO) task to assess multisensory integration in ketamine-treated rats, a well established model of schizophrenia. Ketamine-treated rats displayed a selective MSO task impairment with tactile-visual and olfactory-visual sensory combinations, whereas basic unisensory perception was unaffected. Orbitofrontal cortex (OFC) administration of nicotine or ABT-418, an $\alpha_{4} \beta_{2}$ nicotinic acetylcholine receptor (nAChR) agonist, normalized MSO task performance in ketamine-treated rats and this effect was blocked by $\mathrm{GABA}_{\mathrm{A}}$ receptor antagonism. GABAergic currents were also decreased in OFC of ketamine-treated rats and were normalized by activation of $\alpha_{4} \beta_{2}$ nAChRs. Furthermore, parvalbumin (PV) immunoreactivity was decreased in the OFC of ketamine-treated rats. Accordingly, silencing of PV interneurons in OFC of PV-Cre mice using DREADDs (Designer Receptors Exclusively Activated by Designer Drugs) selectively impaired MSO task performance and this was reversed by ABT-418. Likewise, clozapine- $N$-oxide-induced inhibition of PV interneurons in brain slices was reversed by activation of $\alpha_{4} \beta_{2} \mathrm{nAChRs}$. These findings strongly imply a role for prefrontal GABAergic transmission in the integration of multisensory object features, a cognitive process with relevance to schizophrenia. Accordingly, nAChR agonism, which improves various facets of cognition in schizophrenia, reversed the severe MSO task impairment in this study and appears to do so via a GABAergic mechanism. Interactions between GABAergic and $\mathrm{nAChR}$ receptor systems warrant further investigation for potential therapeutic applications. The novel behavioral procedure introduced in the current study is acutely sensitive to schizophrenia-relevant cognitive impairment and should prove highly valuable for such research.

Key words: DREADDs; ketamine; multisensory integration; nicotine; object perception; rats

\section{Significance Statement}

Adaptive behaviors are driven by integration of information from different sensory modalities. Multisensory integration is disrupted in patients with schizophrenia, but little is known about the neural basis of this cognitive symptom. Development and validation of multisensory integration tasks for animal models is essential given the strong link between functional outcome and cognitive impairment in schizophrenia. We present a novel multisensory object oddity procedure that detects selective multisensory integration deficits in a rat model of schizophrenia using various combinations of sensory modalities. Moreover, converging data are consistent with a nicotinic-GABAergic mechanism of multisensory integration in the prefrontal cortex, results with strong clinical relevance to the study of cognitive impairment and treatment in schizophrenia.

\section{Introduction}

Cognition is severely affected in people suffering from schizophrenia and this aspect of the disorder is strongly linked to functional outcome (Green et al., 2004), highlighting the importance

Received May 19, 2016; revised Sept. 20, 2016; accepted 0ct. 19, 2016.

Author contributions: J.M.C., R.N., D.I.W., J.C.K., C.D.C.B., and B.D.W. designed research;J.M.C., R.N., B.Y.T.C., and

S.D. performed research; J.M.C., R.N., B.Y.T.C., J.C.K., C.D.C.B., and B.D.W. analyzed data; J.M.C., R.N., J.C.K., C.D.C.B., and B.D.W. wrote the paper. of better understanding its behavioral and neural bases. Multisensory integration is a facet of cognition that is distorted in schizophrenia patients (Williams et al., 2010; Stone et al., 2011;

This work was supported by the Natural Sciences and Engineering Research Council (NSERC Discovery Grants to B.D.W., C.D.C.B., and J.C.K. and Postgraduate Scholarship to J.M.C.) and the Canadian Institute of Health Research (CIHR Grant to J.C.K.). B.Y.T.C. was supported by an Ontario Graduate Scholarship and an Ontario Veterinary College Scholarship. We thank Kim Barton, Allegra Drumm, and Michael Wolter for assistance with behavioral experiments.

The authors declare no competing financial interests. 
Tseng et al., 2015), and the CNTRICS (Cognitive Neuroscience Treatment Research to Improve Cognition in Schizophrenia) initiative recognizes the necessity for a "cross-modal integration" task to assess multisensory integration in animal models (Butler et al., 2008).

We developed a tactile-to-visual crossmodal object recognition (CMOR) task to investigate multisensory integration in rodents (Winters and Reid, 2010). Subchronic treatment with the NMDA receptor antagonist ketamine in rats, a well established model of schizophrenia (Jentsch and Roth, 1999; Olney et al., 1999), selectively impairs performance of the CMOR task with even a minimal retention delay (Jacklin et al., 2012; Cloke and Winters, 2015). However, because of the structure of the CMOR task, it is impossible to assess multisensory integration abilities in the absence of mnemonic demand. To explore further the severe multisensory impairment in ketamine-treated rats, we have developed a novel multisensory oddity (MSO) task that is a variation on the perceptual oddity task previously used to study complex visual perception in rodents (Bartko et al., 2007). The MSO task permits assessment of multiple modality combinations (e.g., olfactory-visual) and multisensory integration independent of memory demand. The current study investigated the neural mechanisms underlying multisensory integration deficits and their possible remediation in a rodent model of schizophrenia using the MSO task.

Pharmacological treatments targeting nicotinic acetylcholine receptors (nAChRs) have procognitive effects in schizophrenia patients (Smith et al., 2006; Barr et al., 2008; Lieberman et al., 2013). Accordingly, nicotine and specific nAChR agonists alleviate cognitive deficits in rodent models of schizophrenia (Hashimoto et al., 2008; Wildeboer and Stevens, 2008; Rushforth et al., 2011), including the CMOR impairment reported in ketamine-treated rats (Jacklin et al., 2012; Cloke and Winters, 2015). In the current study, we evaluated whether the ketamineinduced impairment and its remediation by nAChR agonists extend to the MSO task.

We have previously shown that intraorbitofrontal cortex (OFC) administration of the $\alpha_{4} \beta_{2}$ nAChR agonist ABT-418 reverses the CMOR impairment in ketamine-treated rats, and this is blocked by $\mathrm{GABA}_{\mathrm{A}}$ receptor antagonism (Cloke and Winters, 2015). This finding suggests that nAChR activation rescues CMOR performance by enhancing GABAergic activity. In support of this, electrophysiological findings show that activation of nAChRs increases GABAergic currents in the cortex and hippocampus (Alkondon and Albuquerque, 2001; Couey et al., 2007; Aracri et al., 2010). Moreover, the GABAergic system is severely affected in schizophrenia patients because GABAergic markers such as parvalbumin (PV) are reduced in the hippocampus and prefrontal cortex (PFC) (Lewis et al., 2005; Lewis et al., 2012). Similar decreases in GABAergic markers (Behrens et al., 2007; Pratt et al., 2008) and alterations in PV interneuron (PVIN) activity (Homayoun and Moghaddam, 2008; Zhang et al., 2008; Jeevakumar and Kroener, 2016; Kjaerby et al., 2014) are found in the brains of rodents subchronically treated with NMDA receptor antagonists, suggesting that antagonism of NMDA receptors disrupts GABAergic function (Lisman et al., 2008). Interestingly, PVIN activity has been linked to multisensory processing (Olcese et al., 2013; Gogolla et al., 2014) and other cognitive functions

Correspondence should be addressed to Boyer D. Winters, PhD, Department of Psychology, University of Guelph, Guelph, 0N, N1G 2W1, Canada. E-mail: bwinters@uoguelph.ca.

DOI:10.1523/JNEUROSCI.1628-16.2016

Copyright $\odot 2016$ the authors $\quad 0270-6474 / 16 / 3612571-16 \$ 15.00 / 0$
(Murray et al., 2011; Courtin et al., 2014; Kim et al., 2016). We hypothesized that impairment in multisensory integration is related to disrupted PVIN function in the OFC of ketamine-treated rats and that $\mathrm{nAChR}$ stimulation restores behaviorally relevant GABAergic function. The present study provides converging evidence for this hypothesis using complementary techniques from behavioral pharmacology, whole-cell electrophysiology, immunohistochemistry, and DREADDs (Designer Receptors Exclusively Activated by Designer Drugs) experiments specifically targeting PVIN activity during MSO task performance.

\section{Materials and Methods}

\section{Subjects}

Male Long-Evans rats and C57BL/6 mice obtained from Charles River Laboratories and PV-Cre (B6;129P2-Pvalbtm1(cre)Arbr/J; JAX\#008 069) mice obtained from the The Jackson Laboratory and bred as homozygotes were used as subjects. Only rats were food restricted and fed $\sim 25 \mathrm{~g}$ of food each after testing to maintain $85-90 \%$ free-feeding weight. Water was accessible ad libitum except during testing. All procedures adhered to the guidelines of the Canadian Council on Animal Care and were approved by the Animal Care Committees at the University of Guelph and University of Toronto.

\section{Subchronic drug administration}

Rats were randomly assigned to receive either subchronic treatment with ketamine $(30 \mathrm{mg} / \mathrm{kg}$; Bioniche) or saline $(0.9 \% \mathrm{NaCl}, \mathrm{pH}$ 7.0; SigmaAldrich) at a volume of $1 \mathrm{ml} / \mathrm{kg}$ of their body weight (Jacklin et al., 2012; Cloke and Winters, 2015). Treatment consisted of twice daily intraperitoneal administration at 8:00 A.M. and 8:00 P.M. for 10 consecutive days, followed by a $10 \mathrm{~d}$ washout period.

\section{Drugs}

Nicotine [ $(-)$-nicotine hydrogen tartrate salt; dissolved in $0.9 \%$ physiological saline; Sigma-Aldrich) was administered at $0.05,0.2$, and 0.8 $\mathrm{mg} / \mathrm{kg}$ systemically or $0.5,1$, and $2 \mu \mathrm{g} / \mu \mathrm{l}$ intracranially. The $\alpha_{4} \beta_{2} \mathrm{nAChR}$ agonist ABT-418 (dissolved in saline; Sigma-Aldrich) was administered at $0.06,0.1$, and $0.6 \mathrm{mg} / \mathrm{kg}$ systemically or $0.3,1$, and $3 \mu \mathrm{g} / \mu \mathrm{l}$ intracranially. The selective $\alpha_{7}$ nAChR agonist GTS-21 (dissolved in saline; Abcam) was administered at $0.3,1$, and $3 \mathrm{mg} / \mathrm{kg}$ systemically. Nicotinic drugs were administered to rats $20 \mathrm{~min}$ (systemically) or immediately (intracranially) before testing (Jacklin et al., 2012; Cloke and Winters, 2015). The $\mathrm{GABA}_{\mathrm{A}}$ antagonist bicuculline (BIC) (dissolved in $20 \%$ DMSO; Sigma-Aldrich) was administered systemically at $0.5 \mathrm{mg} / \mathrm{kg}$ in rats $20 \mathrm{~min}$ before testing (Cloke and Winters, 2015). Ketamine was administered at $20 \mathrm{mg} / \mathrm{kg}$ systemically in mice $30 \mathrm{~min}$ before testing. Clozapine- $\mathrm{N}$-oxide (CNO; dissolved in 20\% DMSO; obtained from the National Institutes of Health as part of the Rapid Access to Investigate Drug Program funded by the National Institute of Neurological Disorders and Stroke) was administered at $3 \mathrm{mg} / \mathrm{kg}$ systemically in mice $15 \mathrm{~min}$ before testing. ABT-418 was administered systemically at $0.2 \mathrm{mg} / \mathrm{kg}$ in mice $15 \mathrm{~min}$ before testing. Rats were administered each drug at a volume of $1 \mathrm{ml} / \mathrm{kg}$ and mice at a volume of $10 \mathrm{ml} / \mathrm{kg}$. Systemic drugs were administered intraperitoneally.

\section{Surgery}

Rats. After the $10 \mathrm{~d}$ treatment period, surgery was performed on rats during the $10 \mathrm{~d}$ washout period ( 1 week before behavioral testing) for intracranial experiments. Rats were anesthetized with isoflurane (Benson Medical Industries) inhalation anesthetic before and throughout all surgeries. Before surgery, all rats were administered a systemic subcutaneous injection of the analgesic meloxicam ( $5 \mathrm{mg} / \mathrm{ml}$; Boehringer Ingelheim). Rats were then positioned in a stereotaxic frame (Kopf Instruments) with the incisor bar set to $-3.3 \mathrm{~mm}$. The scalp was cut and retracted to expose the skull. Holes were drilled and the guide cannulas were implanted bilaterally according to the following coordinates for the OFC: anteroposterior $(\mathrm{AP})+3.4$; lateral $(\mathrm{L}) \pm 2.2$; dorsoventral (DV) -3.2 relative to bregma (Paxinos and Watson, 2005). For the medial PFC (mPFC) a bilateral cannula was implanted according to the following coordinates: $\mathrm{AP}+3.2 ; \mathrm{L}-0.75 ; \mathrm{DV}-4.0$ relative to bregma. The cannulas were 
secured to the skull using four jeweler screws and dental acrylic. After completion of each surgery, the scalp was sutured and rats recovered on heating pads for $1-2 \mathrm{~h}$ before being returned to their home cages. Behavioral testing began 1 week after surgery. There were 13 rats excluded from behavioral experiments due to mistargeted cannula placement.

Mice. The recombinant AAV-hSyn-FLEX-hM4D-mCherry plasmid (Krashes et al., 2011) was obtained from Dr. Bryan Roth at the University of North Carolina at Chapel Hill and packaged in serotype 2/8 by the University of Pennsylvania Vector Core service. Titers were $1 \times 10^{12}$ particles $/ \mathrm{ml}$.

Mice were anesthetized with isoflurane and mounted onto a stereotaxic frame. The AAV vector containing doubly floxed hM4D-mCherry (AAV2/8-hsyn-FLEX-hM4D-mCherry) was infused into the OFC (AP: $+2.50 \mathrm{~mm}, \mathrm{DV}:-2.60 \mathrm{~mm}, \mathrm{~L}: \pm 1.40 \mathrm{~mm}$ relative to bregma) (Paxinos and Franklin, 2007). A volume of $0.3 \mu \mathrm{l}$ was infused via an internal cannula connected by Tygon tubing to a $10 \mu \mathrm{l}$ Hamilton needle syringe by pressure ejection at a rate of $0.1 \mu \mathrm{l} / \mathrm{min}$. After infusion, the internal cannula was left in place for 10 min to prevent solution backflow. After surgery, mice were single housed and tested 2 weeks afterward to allow for virus expression. There were two mice excluded from behavioral experiments due to mistargeted viral placement.

\section{Infusion procedure}

For intracranial experiments, each animal was gently restrained and infuser cannulas were placed in the guide cannulas. Bilateral simultaneous infusions were delivered by $21 \mu \mathrm{l}$ Hamilton syringes, which were connected to infuser cannulas by propylene tubing. The syringes dispensed $0.5 \mu$ l of drug under the control of a Harvard Apparatus syringe pump for a total of $1 \mathrm{~min}$. After this, the infuser cannulas were left in the guides for another 90 s to allow full diffusion. Before experimentation, all rats underwent two habitation sessions to the infusion procedure. The infusion procedure was duplicated in every way except that the syringes contained no fluid. In addition, all mice underwent two habituation sessions to the systemic injection procedure.

\section{Histology}

After behavioral testing, an intraperitoneal injection of $2 \mathrm{ml}$ of Euthansol was administered to anesthetize the rats. Rats were transcardially perfused with $100 \mathrm{ml}$ of PBS, pH 7.4, followed by $250 \mathrm{ml}$ of $4 \%$ neutral buffered formalin, $\mathrm{pH}$ 7.4. The brains were then extracted, postfixed in $4 \%$ formalin at $4^{\circ} \mathrm{C}$ for $24 \mathrm{~h}$, and then submerged in $20 \%$ sucrose in PBS until they sank. A cryostat was used to cut coronal sections $(60 \mu \mathrm{m})$ through the OFC or mPFC and every fifth section was mounted on a gelatin-coated glass slide and stained with cresyl violet. Slides were examined under a light microscope to confirm cannula placements.

\section{Immunohistochemistry}

After the $10 \mathrm{~d}$ washout period for rats and after testing for mice, rodents were transcardially perfused. Brains were extracted and postfixed in $4 \%$ formalin at $4^{\circ} \mathrm{C}$ for $12 \mathrm{~h}$ and then submerged in $30 \%$ sucrose in PBS at $4^{\circ} \mathrm{C}$ until they sank. Brains were sectioned coronally at $40 \mu \mathrm{m}$ through the PFC using a cryostat. For rats, free-floating brain sections were blocked with $16 \%$ normal goat serum in $0.1 \%$ PBS-Triton for $30 \mathrm{~min}$ at room temperature. Sections were then incubated in $1 \%$ normal goat serum in PBS containing mouse-anti-rat PV (1:1500; Sigma-Aldrich) for $22 \mathrm{~h}$ at $4^{\circ} \mathrm{C}$. After this, sections were incubated in $1 \%$ normal goat serum in PBS containing goat-anti-mouse Cy2 (1:1200; Abcam) for $75 \mathrm{~min}$ at room temperature. Last, sections were incubated in DAPI for $5 \mathrm{~min}$ at room temperature. For mice, free-floating brain sections were blocked with $5 \%$ normal donkey serum in PBS-T $(0.1 \%)$ for $1 \mathrm{~h}$. Sections were then incubated with PBS-T containing rabbit polyclonal anti-PV antibody (1:1000; Abcam) for $48 \mathrm{~h}$ at $4^{\circ} \mathrm{C}$, followed by Alexa Fluor 488 conjugated donkey anti-rabbit secondary antibody (1:1000 in PBS-T; Invitrogen) for $2 \mathrm{~h}$ at room temperature. Slices according to the placement of OFC cannulas were collected for rats and every third section between bregma $2.50 \mathrm{~mm}$ to $2.00 \mathrm{~mm}$ was collected for mice. The sections were mounted and imaged on a confocal laser scanning microscope with a $20 \times$ objective. For rats, total PV-immunoreactive (PV-ir) cells were counted in the lateral orbital (LO) and ventral orbital (VO) subregions of the OFC. For mice, mCherry-positive and PV-ir were counted in a $500 \times 500 \mu \mathrm{m}$ area. The percentage transduction selectivity [(total number of double labeled cells/total number of mCherry-positive cells) $\times 100$ ] and the percentage transduction efficacy [(total number of double-labeled cells/total number of PV-ir cells) $\times 100$ ] were calculated.

\section{Brain slice preparation and electrophysiology}

Coronal slices containing the OFC were prepared from adult rats treated with ketamine or saline after the $10 \mathrm{~d}$ washout period and from mice 2 weeks after virus infusion. Animals were killed by decapitation under inhalant isoflurane and brains were removed quickly and cooled in $4^{\circ} \mathrm{C}$ oxygenated sucrose artificial CSF (ACSF) containing the following (in $\mathrm{mm}$ ): 254 sucrose, $10 \mathrm{D}$-glucose, $26 \mathrm{NaHCO}_{3}, 2 \mathrm{CaCl}_{2}, 2 \mathrm{MgSO}_{4}, 3 \mathrm{KCl}$, and $1.25 \mathrm{NaH}_{2} \mathrm{PO}_{4}, \mathrm{pH}$ 7.4. Brain slices were cut at $400 \mu \mathrm{M}$ thickness using a Leica VT1200 vibrating microtome from anterior to posterior and collected from approximately bregma +4.68 to $+3.72 \mathrm{~mm}$ (rats) and bregma +2.80 to +2.34 (mice). Slices were transferred to oxygenated regular ACSF (composition listed above except $128 \mathrm{~mm} \mathrm{NaCl}$ was substituted for sucrose) maintained at $30^{\circ} \mathrm{C}$ and allowed to recover for at least $2 \mathrm{~h}$. Recordings were made using slices placed within a modified recording chamber (Warner Instruments) mounted on the stage of an Axioskop FS2 Microscope (Carl Zeiss). ACSF was bubbled with carbogen (95\% oxygen and 5\% carbon dioxide) and superfused over the slices at room temperature at a rate of $3-4 \mathrm{ml} / \mathrm{min}$.

For the measurement of postsynaptic GABAergic currents in pyramidal neurons, whole-cell recordings were made using borosilicate glass electrodes (2-5 M $\Omega$ ) containing $50 \mathrm{~mm}$ K-gluconate, $75 \mathrm{~mm} \mathrm{KCl,} 2 \mathrm{~mm}$ $\mathrm{MgCl}_{2}$, 4 mM K $\mathrm{K}_{2}$-ATP, $400 \mu \mathrm{M} \mathrm{Na}$-GTP, $10 \mathrm{~mm} \mathrm{Na}_{2}$ - phosphocreatine, $33 \mu \mathrm{M}$ Alexa Fluor 488 hydrazide (Life Technologies), and $10 \mathrm{~mm}$ HEPES buffer adjusted to $\mathrm{pH} 7.3$ with $\mathrm{KOH}$. The use of this high-chloride intracellular solution in neurons held at $-75 \mathrm{mV}$ allows for the observation $\mathrm{GABA}_{\mathrm{A}}$ receptor activation via positive inward currents that result from chloride exiting the open ligand-gated ion channel (Couey et al., 2007; Bailey et al., 2010). All recordings were performed in layer $2 / 3$ of the OFC, which was visualized by recording immediately dorsal to the apex of layer 1 in the OFC (Van De Werd and Uylings, 2008). Individual pyramidal neurons were visualized using infrared differential interference contrast microscopy and accessed for whole-cell recording. The pyramidal identity was confirmed for each recorded neuron based on its pattern of action potential firing in response to depolarizing current injection and its dendritic morphology, which was visualized using Alexa Fluor 488 hydrazide in the electrode solution and live epifluorescent microscopy. Recordings were made using a Multiclamp $700 \mathrm{~B}$ amplifier, acquired at 20 $\mathrm{kHz}$, and low-pass filtered at $2 \mathrm{kHz}$ using a Digidata 1440A data acquisition system (Molecular Devices).

Using current-clamp mode, changes to membrane potential from rest were first measured in response to positive and negative current steps. This allowed for the determination of neuron basic electrophysiological properties, which were not different between saline- and ketaminetreated rats (data not shown). For experiments measuring GABAergic function, neurons were held at $-75 \mathrm{mV}$ in voltage-clamp mode. Recordings were performed in the continuous presence of $20 \mu \mathrm{M}$ CNQX to block AMPA and kainate glutamate receptors, $200 \mathrm{~nm}$ atropine to block muscarinic receptors, and $10 \mathrm{~nm}$ methyllcaconitine (MLA) to block $\alpha_{7}$ nAChRs. GABAergic spontaneous EPSCs (sEPSCs) were recorded for each neuron during a $30 \mathrm{~s}$ baseline period and then in the presence of 1 $\mathrm{mm}$ acetylcholine (ACh; $15 \mathrm{~s}$ application). Under these recording conditions, the observed sEPSCs were completely blocked by the addition of the $\mathrm{GABA}_{\mathrm{A}}$ receptor competitive antagonist $\mathrm{BIC}$ at a concentration of 10 $\mu \mathrm{M}$ (Couey et al., 2007; Bailey et al., 2010). Analysis of GABAergic sEPSC frequency and amplitude at baseline and during the application of ACh was performed using the Mini Analysis Program (Synaptosoft).

To verify that the excitability of transduced OFC PV interneurons expressing hM4D-mCherry is inhibited by $\mathrm{CNO}$, recordings were made using borosilicate glass electrodes $(2-5 \mathrm{M} \Omega$ ) containing $120 \mathrm{~mm}$ K-gluconate, $5 \mathrm{~mm} \mathrm{KCl}, 2 \mathrm{~mm} \mathrm{MgCl}_{2}, 4 \mathrm{~mm} \mathrm{~K}$-ATP, $400 \mu \mathrm{M} \mathrm{Na}{ }_{2}$-GTP, $10 \mathrm{mM} \mathrm{Na}_{2}$ - phosphocreatine, and $10 \mathrm{~mm}$ HEPES buffer, adjusted to $\mathrm{pH}$ 7.3 with $\mathrm{KOH}$. Individual OFC PV interneurons were identified for mCherry expression using epifluorescence and accessed for electrophysiology with the assistance of infrared differential interference contrast 
A

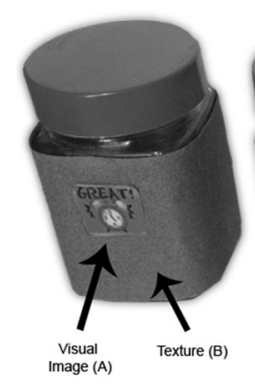

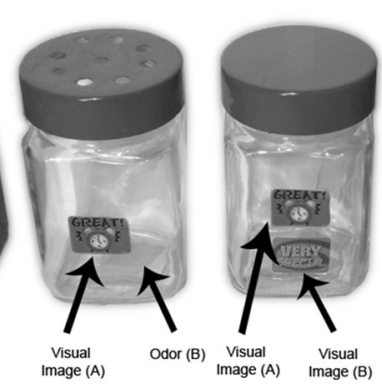
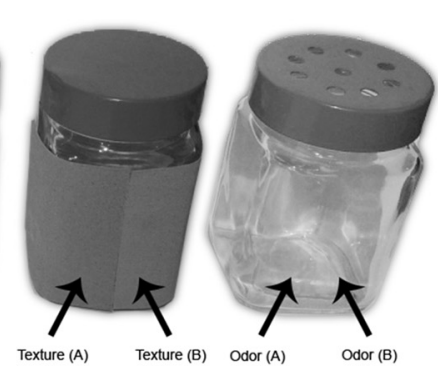

C

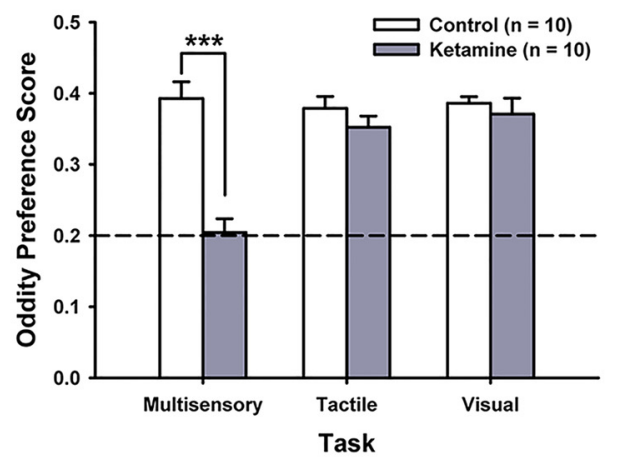

D Olfactory-Visual

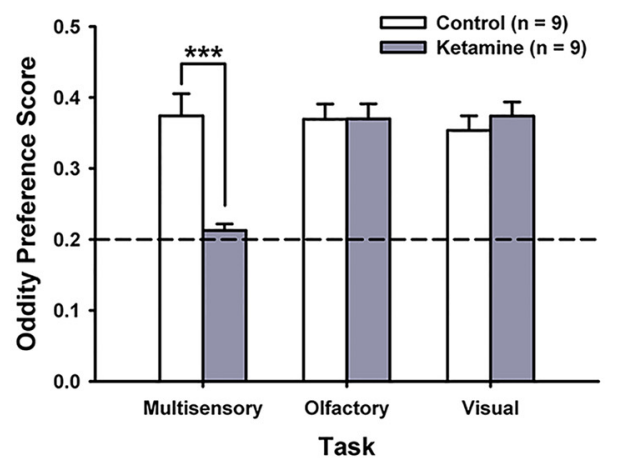

Figure 1. A, Examples of objects used in the various oddity tasks. Each object comprises a combination of two different features, represented here as letters A-D. For the unimodal tasks, these features consist of distinct visual, olfactory, or tactile stimuli. For example, for the unimodal visual oddity task (middle), object AB is identified by the combination of stickers displaying visual image $A$ and visual image $B$. An object in the tactile unimodal oddity task (second from right) consists of a jar with two different grits of sandpaper covering its two halves and an olfactory unimodal object (far right) consists of a jar containing two different odors. For the MSO task, the idea is the same, except that A and B represent features from different sensory modalities; for example, an object consists of a visual image affixed to a jar containing a specific odor (second from left) or a specific grit of sandpaper (far left). The different grits used for any given trial are not visually discriminable. $B$, General oddity task procedure. Five objects are presented simultaneously along the back wall of the open-field arena. Of these objects, two separate pairs contain identical feature combinations (e.g., AB and (D). The fifth object represents a unique (i.e., "odd") configuration of these features (e.g., (B). The various objects can be presented in any arrangement. Rats were given 5 min and mice $10 \mathrm{~min}$ to explore the objects freely. Normal rodents explore the odd object preferentially, thereby demonstrating their ability to discriminate the objects perceptually on the basis of their feature combinations. All tasks are identical in their basic associative requirement, but only the MSO task necessitates multisensory integration for its solution. After the $10 \mathrm{~d}$ washout period, ketamine- and saline-treated rats were tested on the MSO and unimodal oddity tasks. Ketamine-treated rats were selectively impaired on the tactile-visual (C) and olfactory-visual (D) MSO tasks, whereas performance was spared on tactile-, olfactory-, and visual-only oddity task. Dashed line represents chance oddity preference score. Oddity preference scores are displayed for group means ( \pm SEM). ${ }_{* * *} p<0.001$, ketamine versus control rats.

microscopy. The interneuron cell type was confirmed for each recorded neuron based on its pattern of action potential firing in response to depolarizing current injection. Neuron excitability was assessed in current-clamp mode by counting the number of action potentials elicited in response to $500 \mathrm{~ms}$ current steps that ranged from $-40 \mathrm{pA}$ to $+150 \mathrm{pA}$ in $10 \mathrm{pA}$ intervals. Excitability was assessed for each neuron at baseline, after 5 min application of $1 \mu \mathrm{M} \mathrm{CNO}$, and after $30 \mathrm{~s}$ application of $1 \mathrm{~mm}$ ACh in the continuing presence of $1 \mu \mathrm{M} \mathrm{CNO}$. All recordings were made in the presence of $200 \mathrm{~nm}$ atropine and 10 nм MLA.

\section{Oddity tasks}

An open field $(60 \mathrm{~cm} \mathrm{~L} \times 60 \mathrm{~cm} \mathrm{~W} \times 50 \mathrm{~cm} \mathrm{H})$ was used for rats and a smaller trapezoid-shaped open field constructed of opaque white plastic (front wall $39 \mathrm{~cm}$, side wall $14 \mathrm{~cm}$, angled side wall $10 \mathrm{~cm}$, back wall 28 $\mathrm{cm}$ ) was used for mice in oddity experiments. Objects were otherwise identical glass jars ( $10.8 \mathrm{~cm}$ tall with $6.35 \mathrm{~cm}$ diameter) with distinctive visual, tactile, and/or olfactory features added depending on the specific task (see below). Visual features were stickers with images differing in color and shape affixed to the front of each jar. Distinct tactile features were provided by sandpapers of different grit sizes (ranging from 60 to 600 ) to provide unique textural stimuli; the sandpapers for a given trial were not dissimilar visually. Sandpaper was adhered to the exterior of the glass containers for tactile conditions; for tactile-visual combinations, the visual sticker stimuli were affixed to the sandpaper. Distinct stock odors (e.g., vanilla, apple, lemon) were chosen from Bath and Body Works and diluted to $10 \%$ of their initial concentration to reduce their potency. Odors $(1 \mathrm{ml})$ were placed in a small receptacle that was then placed inside the glass jars with a lid that contained holes to allow the rats to sample the olfactory stimuli.

Two types of objects were used: the MSO tasks required multisensory (tactile-visual or olfactory-visual) combinations of features, whereas the control unimodal oddity tasks used objects that combine features from within a single modality (i.e., tactile, visual, or olfactory only). Each unimodal object consisted of two unimodal features (e.g., A and B) to control for the associative nature of the MSO task. Each multisensory object also consisted of two distinct features, but each feature was from a different modality (e.g., visual and tactile or visual and olfactory; Fig. $1 \mathrm{~A}$ ).

Rats and mice were habituated to the apparatus over 2 consecutive days (after the last day of the $10 \mathrm{~d}$ washout period for rats), which consisted of exploration of the empty apparatus ( $5 \mathrm{~min}$ for rats and $10 \mathrm{~min}$ for mice). Each rat in intracranial experiments experienced a mock infusion immediately before each habitation session (see "Infusion procedure"). Behavioral testing commenced $24 \mathrm{~h}$ after the second day of habituation. The general procedure was identical for the MSO and unimodal oddity tasks. On each trial, five objects were equally spread out 
along the back wall of the open field (the longer wall for mouse experiments). Two pairs of identical objects (e.g., ABx2 and CDx2) and an "odd" object consisting of a unique combination of features from the other two pairs (e.g., CB) were presented simultaneously (Fig. 1B). Placement of the odd object was counterbalanced across trials and experiments. Rodents were placed in the open field and allowed to explore the objects freely. Trials were video recorded and scored using a computer program. Exploration was scored when the rodent directed its nose toward the object at a distance of $<2 \mathrm{~cm}$ and/or touched it with its nose or whiskers. The task was completed when a predetermined amount of time had elapsed ( $5 \mathrm{~min}$ for rats and $10 \mathrm{~min}$ for mice). An oddity preference score was calculated, defined as exploration of the odd object divided by total exploration (Bartko et al., 2007); "chance" exploration is therefore 0.2 for an oddity task with 5 objects. Rodents spend a significantly greater proportion of time exploring the single unique object, thereby demonstrating oddity preference based on perceptual binding of the object features (Bartko et al., 2007). MSO and unimodal oddity tasks were counterbalanced across trials. Different object features were used for each trial and counterbalanced across all trials and rodents.

\section{Data analysis}

Behavior was analyzed for rats and mice by taking the mean oddity preference score and total exploration for each condition in each experiment. Mixed-factors or repeated-measures ANOVAs were used to analyze the means of these two measures, and post hoc independent- or paired-samples $t$ tests were used to assess group differences. A Bonferroni correction was applied to account for multiple comparisons. For electrophysiological experiments, mixedfactor ANOVAs, as well as independent- and paired-samples $t$ tests were used. Statistical analyses were conducted with a significance level of $\alpha=0.05$ using SPSS version 23 .

\section{Results}

Ketamine-treated rats exhibit selective MSO task impairment Ketamine-treated rats display a selective multisensory impairment in the CMOR task (Jacklin et al., 2012; Cloke and Winters, 2015). We have developed the MSO tasks to overcome the limitations of the CMOR task and to advance exploration of the multisensory impairment in schizophrenia models. Accordingly, we tested two separate groups of saline- and ketamine-treated rats on the newly developed tactile-visual or olfactory-visual MSO tasks, as well as the unimodal control tasks (tactile, olfactory, and/or visual only).

Ketamine-treated rats were selectively impaired on the tactile-visual [Fig. 1c; Group $\times \operatorname{Task}\left(F_{(2,36)}=15.32, p<0.001\right)$, Group $\left(F_{(1,18)}=21.76, p<0.001\right)$, Task $\left(F_{(2,36)}=12.06, p<\right.$ $0.001)$ ] and olfactory-visual [Fig. 1d; Group $\times$ Task $\left(F_{(2,32)}=\right.$ $10.74, p<0.001)$, Group $\left(F_{(1,16)}=7.30, p<0.05\right)$, Task $\left(F_{(2,32)}=\right.$ $7.77, p<0.01)]$ MSO tasks. Post hoc independent-samples $t$ tests indicated significant differences between ketamine- and salinetreated rats on the tactile-visual $\left(t_{(18)}=6.18, p<0.001\right)$ and olfactory-visual $\left(t_{(16)}=4.98, p<0.001\right)$ MSO tasks, but not the unimodal control tasks $(p>0.05)$. The analysis of total object exploration for the olfactory-visual MSO experiment revealed a significant main effect of Task $\left(F_{(2,32)}=8.63, p<0.01\right)$ and Group $\left(F_{(1,16)}=8.80, p<0.01\right)$, but no significant interaction. Exploration was significantly lower in the visual-only task $(p<$ 0.01 ) and higher overall in ketamine-treated rats; however, task performance did not appear to be affected by these differences (Table 1). These results suggest a generalized multisensory impairment in ketamine-treated rats that is perceptual in nature, complementing and extending our previous findings with CMOR.
Table 1. Control measures collected from rat oddity experiments for each condition

\begin{tabular}{|c|c|c|c|}
\hline \multirow[b]{2}{*}{ Experiments } & \multirow[b]{2}{*}{ Condition } & \multicolumn{2}{|c|}{ Total object exploration } \\
\hline & & Control & Ketamine \\
\hline \multirow{3}{*}{$\begin{array}{l}\text { TAC-VIS MSO + controls } \\
\text { (TAC and VIS only) }\end{array}$} & TAC-VIS & $14.03 \pm 1.33$ & $14.64 \pm 1.32$ \\
\hline & TAC & $13.59 \pm 1.79$ & $12.61 \pm 1.42$ \\
\hline & VIS & $12.11 \pm 2.63$ & $12.51 \pm 1.40$ \\
\hline \multirow{3}{*}{$\begin{array}{l}\text { OLF-VIS MSO + controls } \\
\text { (OLF and VIS only) }\end{array}$} & OLF-VIS & $14.31 \pm 1.48$ & $19.74 \pm 1.69$ \\
\hline & OLF & $14.87 \pm 1.48$ & $17.33 \pm 1.58$ \\
\hline & VIS & $10.36 \pm 0.92$ & $14.09 \pm 0.74$ \\
\hline \multirow[t]{4}{*}{ TAC-VIS MSO: systemic nicotine } & VEH & $10.67 \pm 0.56$ & $11.31 \pm 1.00$ \\
\hline & $0.05 \mathrm{mg} / \mathrm{kg}$ & $10.10 \pm 0.79$ & $11.65 \pm 1.02$ \\
\hline & $0.2 \mathrm{mg} / \mathrm{kg}$ & $11.71 \pm 0.77$ & $12.39 \pm 0.88$ \\
\hline & $0.8 \mathrm{mg} / \mathrm{kg}$ & $12.27 \pm 1.07$ & $12.05 \pm 0.93$ \\
\hline \multirow[t]{4}{*}{ OLF-VIS MSO: systemic nicotine } & VEH & $10.37 \pm 1.10$ & $12.46 \pm 1.83$ \\
\hline & $0.05 \mathrm{mg} / \mathrm{kg}$ & $12.38 \pm 0.96$ & $11.75 \pm 1.29$ \\
\hline & $0.2 \mathrm{mg} / \mathrm{kg}$ & $11.91 \pm 0.98$ & $11.19 \pm 1.01$ \\
\hline & $0.8 \mathrm{mg} / \mathrm{kg}$ & $11.73 \pm 0.66$ & $12.68 \pm 1.08$ \\
\hline \multirow[t]{4}{*}{ TAC-VIS MSO: systemic ABT-418 } & VEH & $8.92 \pm 0.43$ & $8.51 \pm 0.92$ \\
\hline & $0.06 \mathrm{mg} / \mathrm{kg}$ & $7.05 \pm 0.60$ & $8.53 \pm 1.07$ \\
\hline & $0.1 \mathrm{mg} / \mathrm{kg}$ & $8.30 \pm 0.93$ & $7.99 \pm 0.67$ \\
\hline & $0.6 \mathrm{mg} / \mathrm{kg}$ & $7.88 \pm 0.43$ & $8.44 \pm 0.94$ \\
\hline \multirow[t]{4}{*}{ OLF-VIS MSO: systemic ABT-418 } & VEH & $16.33 \pm 1.63$ & $21.06 \pm 1.89$ \\
\hline & $0.06 \mathrm{mg} / \mathrm{kg}$ & $17.60 \pm 1.56$ & $22.10 \pm 1.63$ \\
\hline & $0.1 \mathrm{mg} / \mathrm{kg}$ & $17.31 \pm 2.00$ & $19.66 \pm 2.29$ \\
\hline & $0.6 \mathrm{mg} / \mathrm{kg}$ & $19.30 \pm 2.07$ & $19.79 \pm 2.57$ \\
\hline \multirow[t]{4}{*}{ TAC-VIS MS0: systemic GTS-21 } & VEH & $9.37 \pm 0.63$ & $11.62 \pm 1.12$ \\
\hline & $0.3 \mathrm{mg} / \mathrm{kg}$ & $10.10 \pm 0.91$ & $11.20 \pm 1.44$ \\
\hline & $1 \mathrm{mg} / \mathrm{kg}$ & $11.99 \pm 1.29$ & $12.25 \pm 1.09$ \\
\hline & $3 \mathrm{mg} / \mathrm{kg}$ & $11.45 \pm 0.87$ & $11.59 \pm 0.84$ \\
\hline \multirow[t]{4}{*}{ OLF-VIS MS0: systemic GTS-21 } & VEH & $19.22 \pm 2.79$ & $17.42 \pm 2.56$ \\
\hline & $0.3 \mathrm{mg} / \mathrm{kg}$ & $16.22 \pm 1.67$ & $17.50 \pm 1.65$ \\
\hline & 1 mg/kg & $18.05 \pm 1.23$ & $15.97 \pm 1.00$ \\
\hline & $3 \mathrm{mg} / \mathrm{kg}$ & $19.00 \pm 2.18$ & $20.37 \pm 2.39$ \\
\hline \multirow[t]{4}{*}{ TAC-VIS MSO: intra-OFC nicotine } & VEH & $13.69 \pm 1.07$ & $12.67 \pm 0.70$ \\
\hline & $0.05 \mu \mathrm{g}$ & $12.82 \pm 2.00$ & $13.69 \pm 1.96$ \\
\hline & $1 \mu \mathrm{g}$ & $14.07 \pm 0.99$ & $12.92 \pm 1.10$ \\
\hline & $2 \mu \mathrm{g}$ & $13.14 \pm 0.99$ & $11.95 \pm 1.28$ \\
\hline \multirow[t]{4}{*}{ OLF-VIS MSO: intra-0FC nicotine } & VEH & $33.44 \pm 2.90$ & $26.22 \pm 2.87$ \\
\hline & $0.05 \mu \mathrm{g}$ & $33.72 \pm 2.98$ & $25.51 \pm 1.90$ \\
\hline & $1 \mu \mathrm{g}$ & $26.28 \pm 0.64$ & $24.93 \pm 2.32$ \\
\hline & $2 \mu \mathrm{g}$ & $32.38 \pm 3.50$ & $27.79 \pm 2.33$ \\
\hline \multirow[t]{4}{*}{ TAC-VIS MSO: intra-mPFC nicotine } & VEH & $10.26 \pm 1.54$ & $15.13 \pm 1.73$ \\
\hline & $0.05 \mu \mathrm{g}$ & $11.02 \pm 1.13$ & $15.00 \pm 1.11$ \\
\hline & $1 \mu \mathrm{g}$ & $9.10 \pm 1.25$ & $13.10 \pm 1.06$ \\
\hline & $2 \mu \mathrm{g}$ & $11.61 \pm 0.93$ & $12.43 \pm 1.40$ \\
\hline \multirow[t]{4}{*}{ OLF-VIS MSO: intra-mPFC nicotine } & VEH & $17.60 \pm 1.84$ & $20.64 \pm 3.00$ \\
\hline & $0.05 \mu \mathrm{g}$ & $16.49 \pm 1.45$ & $19.13 \pm 1.79$ \\
\hline & $1 \mu \mathrm{g}$ & $18.03 \pm 2.60$ & $20.38 \pm 2.07$ \\
\hline & $2 \mu \mathrm{g}$ & $16.87 \pm 2.54$ & $18.32 \pm 1.84$ \\
\hline TAC-VIS MS0: intra-OFC ABT-418 & VEH & $18.07 \pm 1.93$ & $14.57 \pm 1.63$ \\
\hline & $0.3 \mu \mathrm{g}$ & $14.21 \pm 0.86$ & $15.63 \pm 1.00$ \\
\hline & $1 \mu \mathrm{g}$ & $13.12 \pm 1.94$ & $13.03 \pm 1.70$ \\
\hline & $3 \mu \mathrm{g}$ & $14.44 \pm 3.37$ & $12.07 \pm 1.49$ \\
\hline OLF-VIS MSO: intra-OFC ABT-418 & VEH & $23.33 \pm 2.15$ & $26.18 \pm 2.26$ \\
\hline & $0.3 \mu \mathrm{g}$ & $27.29 \pm 1.48$ & $23.44 \pm 2.13$ \\
\hline & $1 \mu g$ & $27.43 \pm 1.83$ & $22.42 \pm 3.08$ \\
\hline & $3 \mu \mathrm{g}$ & $26.83 \pm 3.00$ & $25.06 \pm 2.17$ \\
\hline TAC-VIS MSO: intra-0FC ABT-418 + & VEH/VEH & $8.54 \pm 0.95$ & $11.82 \pm 1.20$ \\
\hline systemic bicuculline & VEH/BIC & $8.51 \pm 0.76$ & $11.68 \pm 1.28$ \\
\hline & ABT/VEH & $8.67 \pm 0.72$ & $8.12 \pm 0.89$ \\
\hline & ABT/BIC & $8.40 \pm 0.88$ & $10.01 \pm 1.43$ \\
\hline OFC-VIS MSO: intra-0FC ABT-418 + & VEH/VEH & $22.69 \pm 1.67$ & $21.49 \pm 2.19$ \\
\hline systemic bicuculline & VEH/BIC & $21.94 \pm 1.59$ & $21.17 \pm 1.95$ \\
\hline & ABT/VEH & $21.52 \pm 2.75$ & $18.95 \pm 1.71$ \\
\hline & ABT/BIC & $20.18 \pm 1.79$ & $18.61 \pm 2.26$ \\
\hline
\end{tabular}

Data are expressed as the mean \pm SEM of the total time in seconds spent exploring the objects. OLF, Olfactory; TAC, tactile; VIS, visual. 


\section{A Tactile-Visual}

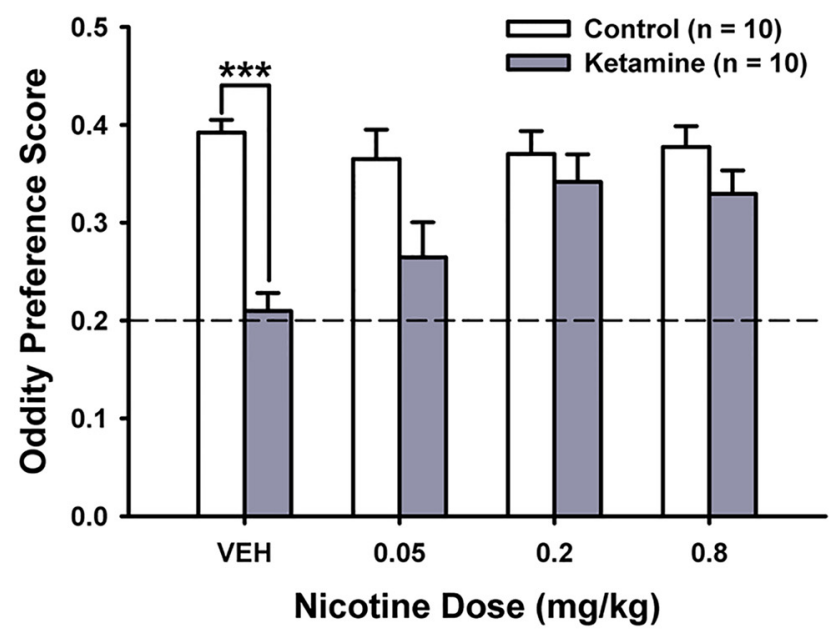

\section{B Olfactory-Visual}

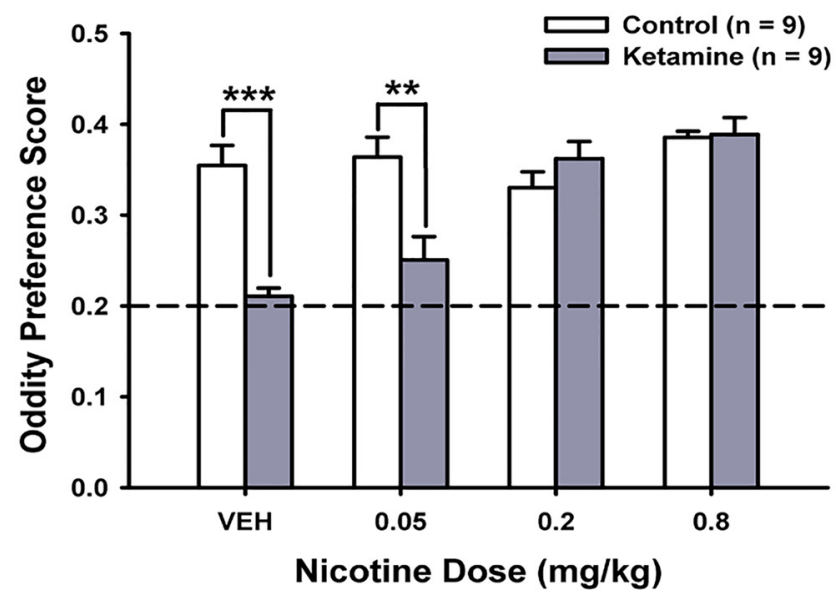

Figure 2. After the $10 \mathrm{~d}$ washout period, ketamine- and saline-treated rats were administered nicotine $(0.05,0.2$, and $0.8 \mathrm{mg} / \mathrm{kg})$ systemically $20 \mathrm{~min}$ before testing. Nicotine dose dependently restored performance of the tactile-visual $(\boldsymbol{A})$ and olfactory-visual $(\boldsymbol{B})$ MSO tasks in ketamine-treated rats. Dashed line represents chance oddity preference score. Oddity preference scores are displayed for group means ( \pm SEM). ${ }^{* *} p<0.01$; ${ }^{* *} p<0.001$, ketamine versus control rats.

$\alpha_{4} \beta_{2}$ nAChRs are responsible for the ameliorative effect of nicotine in ketamine-treated rats

The remediating effect of systemic nicotine and specific $\mathrm{nAChR}$ agonists in ketamine-treated rats was examined using the MSO tasks. Systemic administration of nicotine dose dependently reversed the tactile-visual [Fig. $2 A$; Group $\times$ Dose $\left(F_{(3,54)}=3.55\right.$, $p<0.05)$, Group $\left(F_{(1,18)}=32.50, p<0.001\right)$, Dose $\left(F_{(3,54)}=\right.$ 2.26, $p=0.092)$ ] and olfactory-visual (Fig. $2 B$; Group $\times$ Dose $\left(F_{(3,48)}=11.58, p<0.001\right)$, Group $\left(F_{(1,16)}=14.84, p<0.01\right)$, Dose $\left.\left(F_{(3,48)}=13.11, p<0.001\right)\right]$ MSO task deficits in ketaminetreated rats. Post hoc independent-samples $t$ tests revealed significant differences between ketamine- and saline-treated rats in the vehicle $(\mathrm{VEH})$ condition on tactile-visual MSO $(p<0.001)$ and differences in the $\mathrm{VEH}(p<0.001)$ and $0.05 \mathrm{mg} / \mathrm{kg}$ nicotine $(p<$
$0.01)$ conditions on olfactory-visual MSO. The analysis of total object exploration revealed no significant interaction or main effects, suggesting no obvious differences in general exploratory behavior (Table 1).

Likewise, systemic administration of the $\alpha_{4} \beta_{2}$ nAChR agonist ABT-418 restored the tactile-visual [Fig. 3A; Group $\times$ Dose $\left(F_{(3,54)}=4.61, p<0.01\right)$, Group $\left(F_{(1,18)}=8.47, p<0.01\right)$, Dose $\left.\left(F_{(3,54)}=3.81, p<0.05\right)\right]$ and olfactory-visual [Fig. 3B; Group $\times$ $\operatorname{Dose}\left(F_{(3,54)}=10.25, p<0.001\right), \operatorname{Group}\left(F_{(1,18)}=19.14, p<0.001\right)$, Dose $\left.\left(F_{(3,54)}=10.34, p<0.001\right)\right]$ MSO impairments in ketaminetreated rats. Post hoc independent-samples $t$ tests revealed significant differences between ketamine- and saline-treated rats in the VEH condition on the tactile-visual MSO task $\left(t_{(18)}=4.65, p<0.001\right)$, but no significant differences in the other dose conditions $(p>$ $0.05)$. In addition, significant differences between ketamine- and saline-treated rats were found in the VEH $\left(t_{(18)}=6.25, p<0.001\right)$ and $0.06 \mathrm{mg} / \mathrm{kg} \mathrm{ABT}-418\left(t_{(18)}=4.40, p<0.001\right)$ conditions on the olfactory-visual MSO task, but no significant differences in the other dose conditions $(p>0.05)$. There were no differences in general object exploration (Table 1$)$.

Unlike ABT-418, the $\alpha_{7}$ nAChR agonist GTS-21 did not affect the tactile-visual [Fig. $3 C$; Group $\times$ Dose $\left(F_{(3,54)}=0.33, p=\right.$ $0.806)$, Group $\left(F_{(1,18)}=239.64, p<0.001\right)$, Dose $\left(F_{(3,54)}=0.50\right.$, $p=0.684)]$ or olfactory-visual (Fig. $3 D$; Group $\times \operatorname{Dose}\left(F_{(3,54)}=\right.$ $0.51, p=0.678)$, Group $\left(F_{(1,18)}=84.28, p<0.001\right)$, Dose $\left.\left(F_{(3,54)}=2.07, p=0.115\right)\right]$ MSO task impairment in ketaminetreated rats. Our systemic findings therefore indicate that the remediating effect of nicotine in ketamine-treated rats is the result of $\alpha_{4} \beta_{2} \mathrm{nAChR}$ activation.

$\boldsymbol{\alpha}_{4} \boldsymbol{\beta}_{2} \mathrm{nAChRs}$ in the OFC reverse the MSO task impairment in ketamine-treated rats

Alterations in the PFC of schizophrenia patients are associated with cognitive dysfunction (Lewis et al., 2012). OFC abnormalities in patients with schizophrenia, such as hypofrontality, decreased volume, and connectivity to other regions, are commonly found (Shenton et al., 2001; Bellani et al., 2010; Kanahara et al., 2013; Eryilmaz et al., 2016). The OFC region of the PFC receives multiple sensory inputs from various cortical regions (Fuster, 1997; Ongür and Price, 2000; Uylings et al., 2003) and has been shown to be important for multisensory integration in rodents and nonhuman primates (Lipton et al., 1999; Fuster et al., 2000). These findings suggest that dysfunction of this region may be related to a multisensory impairment in ketamine-treated rats. Our previous data support a role for the OFC in multisensory integration because lesions of the OFC, but not mPFC, impair CMOR performance selectively in rats (Reid et al., 2014). Furthermore, intra-OFC administration of nicotine or ABT-418 reverses the CMOR impairment in ketamine-treated rats (Cloke and Winters, 2015) and there is greater $\alpha_{4} \beta_{2} \mathrm{nAChR}$ binding compared with controls and $\alpha_{7} \mathrm{nAChR}$ binding in the OFC of schizophrenia patients (Marutle et al., 2001). We therefore tested for generalization of these effects using the MSO tasks.

Rats had cannulas implanted bilaterally in the OFC (Fig. $4 A, B$ ) or mPFC (Fig. $5 A, B$ ). mPFC cannulations mainly terminated within the prelimbic region. Intra-OFC nicotine reversed the tactile-visual [Fig. $4 C$; Group $\times$ Dose $\left(F_{(3,45)}=4.98, p<\right.$ $0.01)$, Group $\left(F_{(1,15)}=45.71, p<0.001\right)$, Dose $\left(F_{(3,45)}=6.16\right.$, $p<0.001)$ ] and olfactory-visual (Fig. $4 D$; Group $\times$ Dose $\left(F_{(3,45)}=28.64, p<0.001\right)$, Group $\left(F_{(1,15)}=15.71, p<0.001\right)$, Dose $\left.\left(F_{(3,45)}=5.24, p<0.01\right)\right]$ MSO task impairments in ketamine-treated rats. Post hoc independent-samples $t$ tests revealed significant differences between ketamine- and saline- 
A

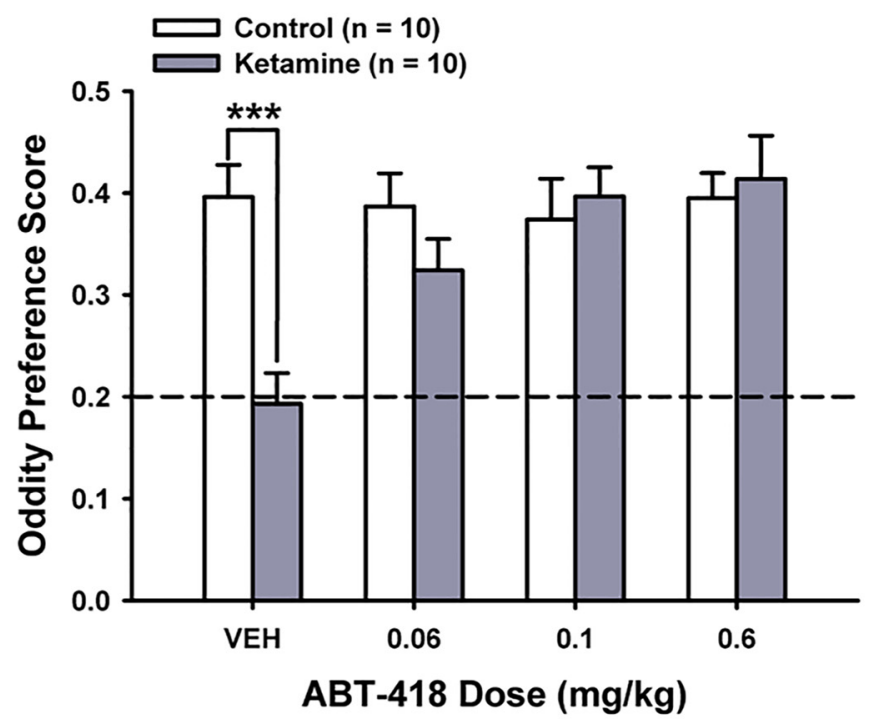

c Tactile-Visual

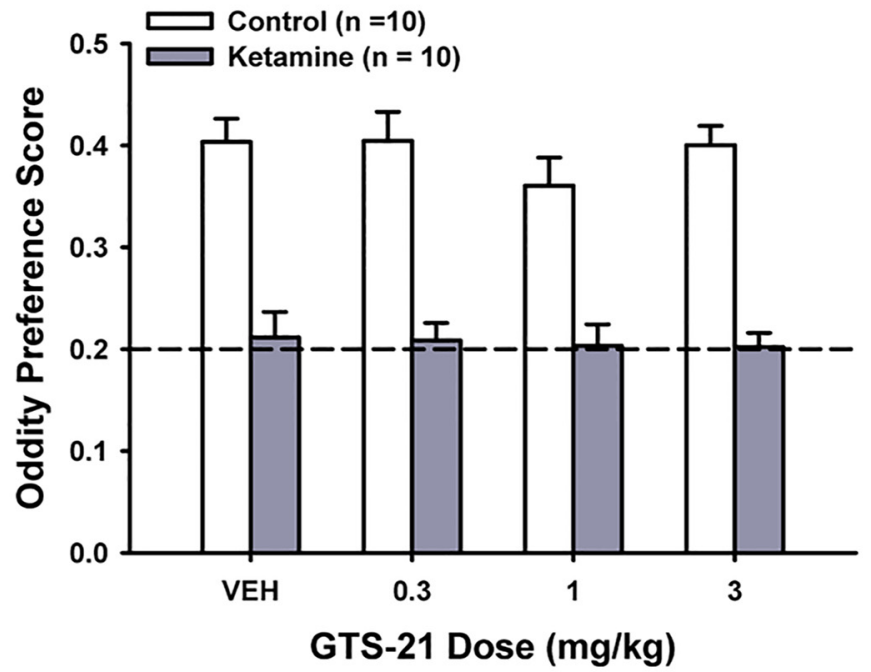

B

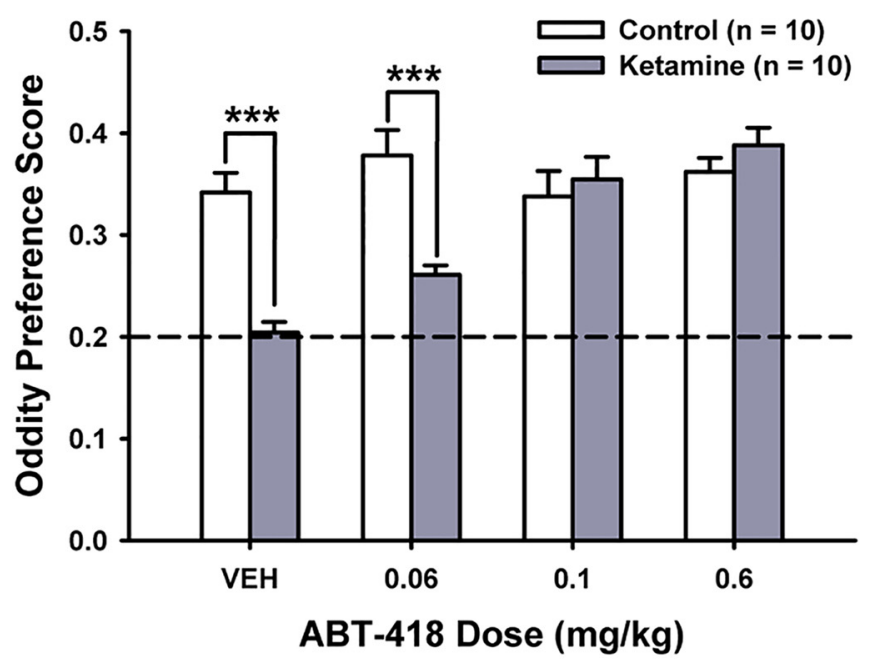

D
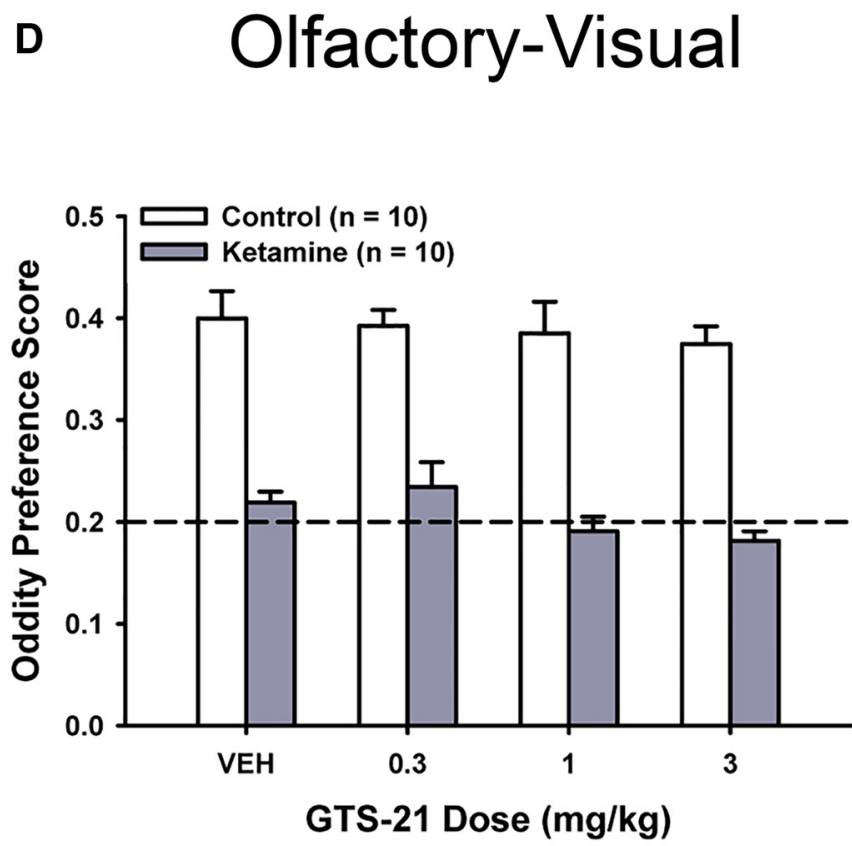

Figure 3. After the $10 \mathrm{~d}$ washout period, ketamine- and saline-treated rats were administered the selective $\alpha_{4} \beta_{2} \mathrm{nAChR}$ agonist ABT- $418(0.06,0.1$, and $0.6 \mathrm{mg} / \mathrm{kg})$ or GTS-21 (0.3, 1 , and 3 $\mathrm{mg} / \mathrm{kg}$ ) systemically $20 \mathrm{~min}$ before testing. ABT-418 dose dependently rescued performance of the tactile-visual $(\boldsymbol{A})$ and olfactory-visual (B) MSO tasks in ketamine-treated rats. GTS-21 did not affect performance of the tactile-visual $(\boldsymbol{C})$ and olfactory-visual (D) MSO tasks in ketamine-treated rats. Dashed line represents chance oddity preference score. Oddity preference scores are displayed for group means ( \pm SEM). ${ }^{* *} p<0.001$, ketamine versus control rats.

treated rats in $\mathrm{VEH}$ and $0.5 \mu \mathrm{g}$ nicotine conditions on the tactilevisual (VEH: $t_{(15)}=6.80, p<0.001 ; 0.5 \mu$ g nicotine: $t_{(15)}=4.01$, $p<0.01)$ and olfactory-visual (VEH: $t_{(15)}=10.41, p<0.001 ; 0.5$ $\mu$ g nicotine: $\left.t_{(15)}=5.74, p<0.001\right)$ MSO tasks, but no significant differences in the other dose conditions $(p>0.05)$. The analysis of total object exploration revealed a main effect of group in the olfactory-visual MSO experiment $\left(F_{(1,15)}=4.92, p<0.05\right)$, but no significant interaction (Table 1 ); all other effects were nonsignificant.

Intra-mPFC nicotine did not affect tactile-visual [Fig. 5C; Group $\times$ Dose $\left(F_{(3,42)}=1.03, p=0.388\right)$, Group $\left(F_{(1,14)}=\right.$
109.49, $p<0.001)$, Dose $\left.\left(F_{(3,42)}=0.779, p=0.513\right)\right]$ or olfactory-visual (Fig. $5 D$; Group $\times$ Dose $\left(F_{(3,42)}=1.74, p=0.173\right.$ ), Group $\left(F_{(1,14)}=115.50, p<0.001\right)$, Dose $\left(F_{(3,42)}=0.526, p=\right.$ $0.667)$ ] MSO task performance in ketamine-treated rats. The analysis of total object exploration revealed a main effect of group in the tactile-visual MSO experiment $\left(F_{(1,14)}=17.38, p<0.001\right)$ such that ketamine-treated rats explored more, but no significant interaction was found (Table 1). This result suggests that the effect of nicotine is regionally specific within the PFC.

Intra-OFC ABT-418 also dose dependently reversed the tactile-visual [Fig. 6A; Group $\times$ Dose $\left(F_{(3,45)}=6.46, p<\right.$ 
A

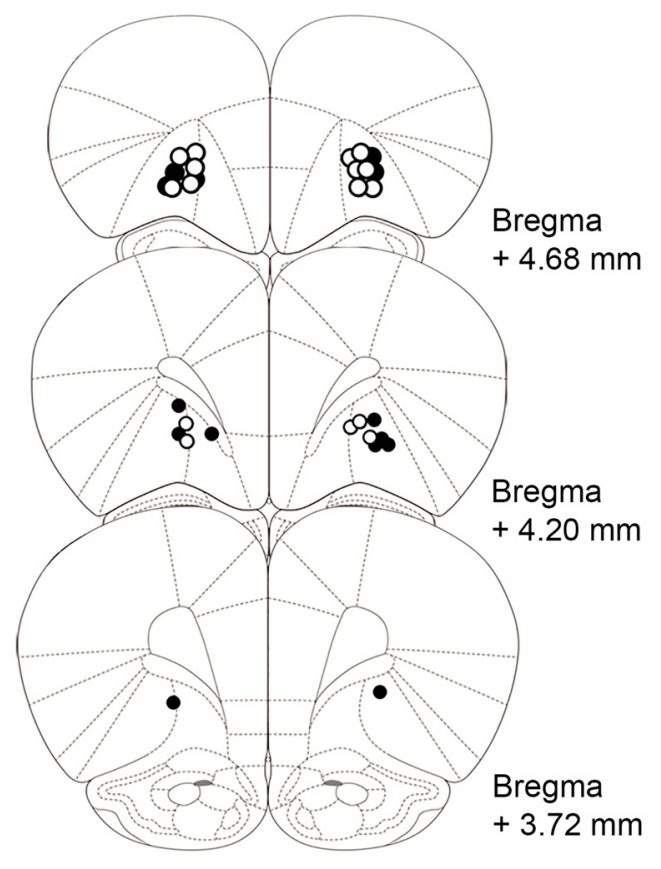

B

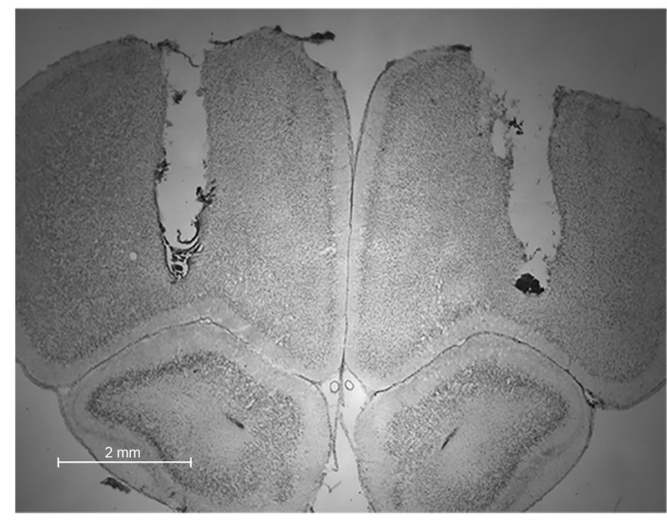

C

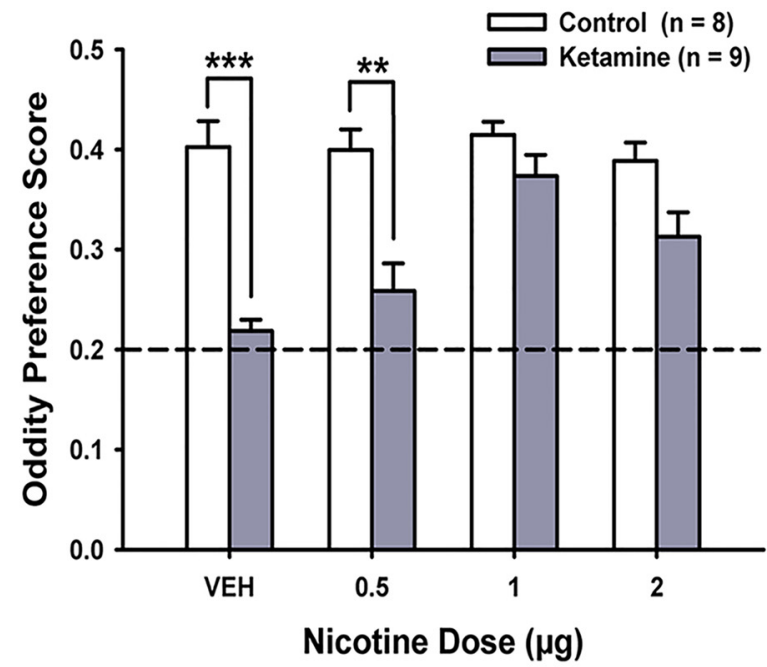

Olfactory-Visual

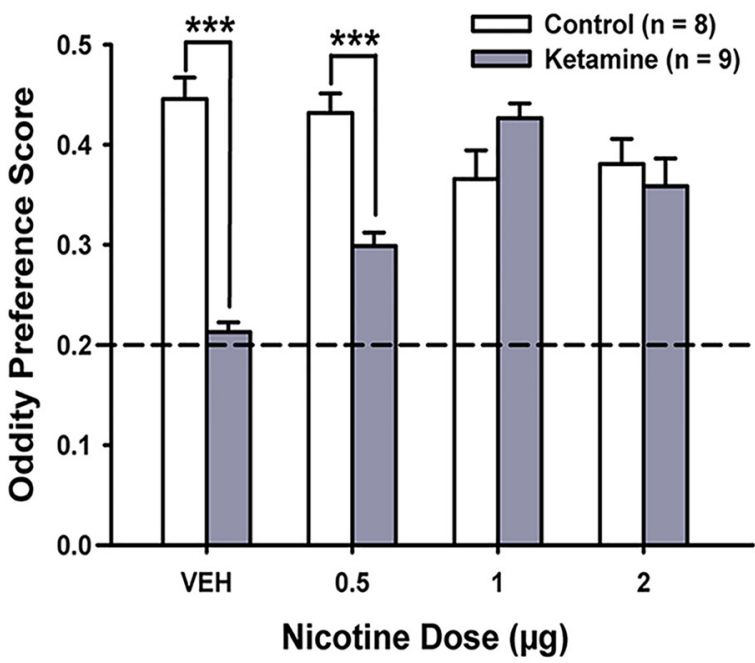

Figure 4. $\quad A$, Cannulation of rat OFC. Shown is a schematic representation of the infusion needle tip placements from a typical group of animals (intra-OFC nicotine experiment; $n=17$ ). These placements are representative of needle tip locations in all animals (closed circles $=$ saline-treated rats; open circles $=$ ketamine-treated rats) included in the behavioral analyses of the present study. Cannulas were consistently located between $+3.72 \mathrm{~mm}$ and $+4.68 \mathrm{~mm}$ anterior to bregma. Some needle tips overlap in the figure. $\boldsymbol{B}$, Representative Niss-stained section of a bilateral $0 \mathrm{FC}$ cannulation in rat. After the $10 \mathrm{~d}$ washout period, ketamine- and saline-treated rats were infused with nicotine $(0.5,1$, and $2 \mu \mathrm{g})$ into the $\mathrm{OFC}$ immediately before testing. Intra- $0 \mathrm{FC}$ nicotine dose dependently restored performance of the tactile-visual $(\boldsymbol{C})$ and olfactory-visual $(\boldsymbol{D})$ MSO tasks in ketamine-treated rats. Dashed line represents chance oddity preference score. Oddity preference scores are displayed for group means $\left( \pm\right.$ SEM). ${ }^{* *} p<0.01 ;{ }^{* * *} p<0.001$, ketamine versus control rats.

0.001), Group $\left(F_{(1,15)}=22.88, p<0.001\right)$, Dose $\left(F_{(3,45)}=\right.$ $1.83, p=0.156)]$ and olfactory-visual [Fig. $6 B$; Group $\times$ Dose $\left(F_{(3,45)}=8.62, p<0.001\right)$, Group $\left(F_{(1,15)}=32.26, p<0.001\right)$, Dose $\left.\left(F_{(3,45)}=5.42, p<0.01\right)\right]$ MSO task impairments in ketamine-treated rats. Post hoc independent-samples $t$ tests indicated significant differences between ketamine- and saline-treated rats in $\mathrm{VEH}$ and $0.3 \mu \mathrm{g}$ of ABT-418 conditions on the tactile-visual (VEH: $t_{(15)}=4.85, p<0.001 ; 0.3 \mu \mathrm{g}$ ABT-418: $\left.t_{(15)}=2.87, p<0.0125\right)$ and olfactory-visual (VEH: $t_{(15)}=5.41, p<0.001 ; 0.3 \mu \mathrm{g} \mathrm{ABT}-418: t_{(15)}=4.85, p<$
0.001) MSO tasks, but no significant differences in the other dose conditions $(p>0.05)$. There were no differences in object exploration (Table 1 ). Therefore, $\alpha_{4} \beta_{2} \mathrm{nAChR}$ activation within the OFC remediates the MSO impairment in ketaminetreated rats.

$\mathrm{GABA}_{\mathrm{A}}$ receptor blockade inhibits the remediating effect of $\boldsymbol{\alpha}_{4} \boldsymbol{\beta}_{2}$ nAChRs in the OFC of ketamine-treated rats

These experiments explored the potential interaction between $\alpha_{4} \beta_{2}$ nAChRs and the GABAergic system in ketamine-treated 
A

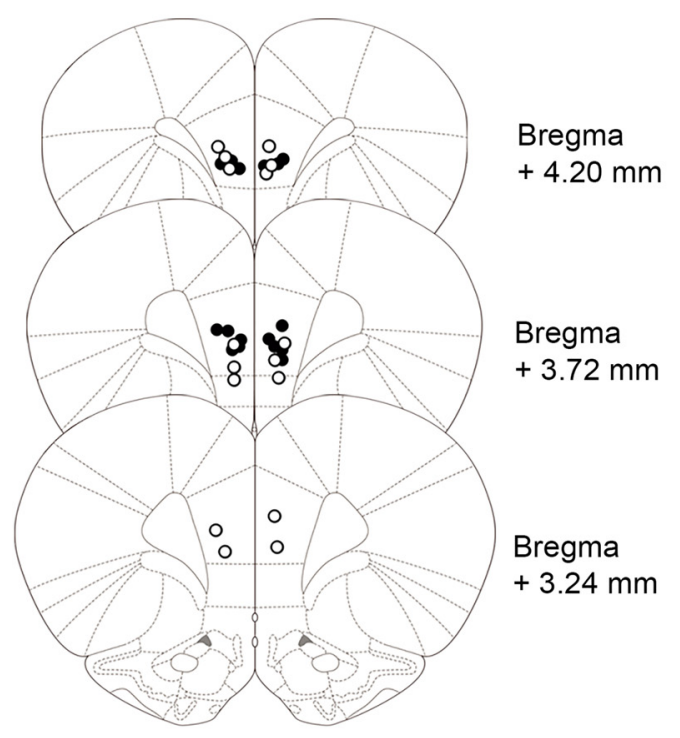

c Tactile-Visual

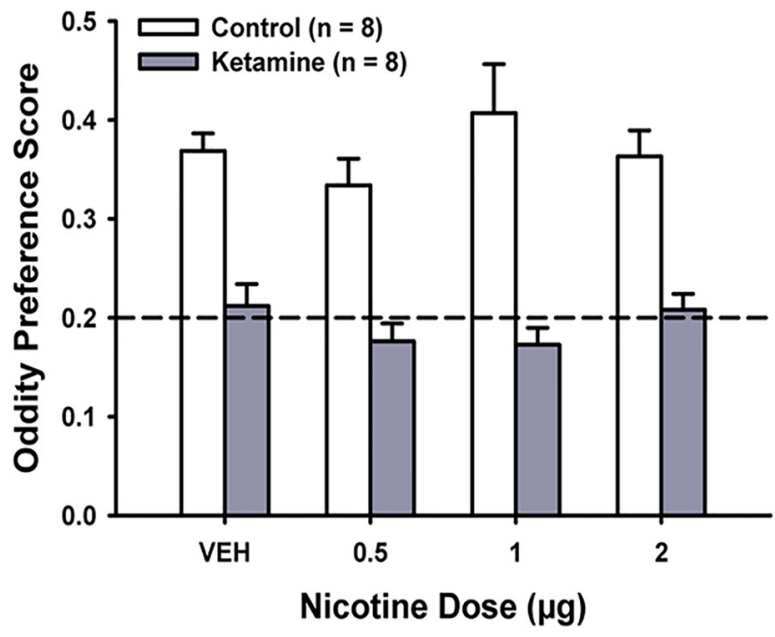

D Olfactory-Visual

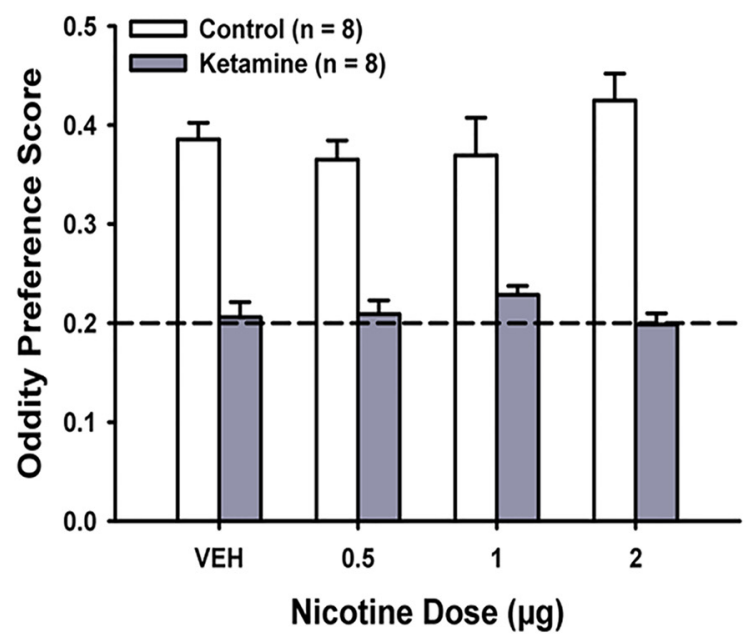

Figure 5. A, Cannulation of rat $\mathrm{mPFC}$. Shown is a schematic representation of the infusion needle tip placements from all rats $(n=16)$. These placements represent needle tip locations in all rats (closed circles = saline-treated rats; open circles = ketamine-treated rats) included in the behavioral analyses of the present study. Cannula tips were consistently located between 3.24 and $4.20 \mathrm{~mm}$ anterior to bregma and typically within prelimbic cortex. Some needle tips overlap in the figure. $\boldsymbol{B}$, Representative section of a bilateral mPFC cannulation in rat. After the $10 \mathrm{~d}$ washout period, ketamine- and saline-treated rats were infused with nicotine $(0.5,1$, and $2 \mu \mathrm{g})$ into the mPFC immediately before testing. Intra-mPFC nicotine did not affect performance of the tactile-visual (C) or olfactory-visual (D) MSO tasks in ketamine-treated rats. Dashed line represents chance oddity preference score. $0 \mathrm{ddity}$ preference scores are displayed for group means ( \pm SEM).

rats. We hypothesized that prefrontal $\alpha_{4} \beta_{2}$ nAChRs restore multisensory cognition in ketamine-treated rats by enhancing GABA release. Therefore, rats were implanted with bilateral cannulas in the OFC and infused with ABT-418 $(3 \mu \mathrm{g})$ and systemically administered the $\mathrm{GABA}_{\mathrm{A}}$ antagonist $\mathrm{BIC}(0.5 \mathrm{mg} /$ $\mathrm{kg}$ ) before testing. BIC blocked the remediating effect of intraOFC ABT-418 in ketamine-treated rats on tactile-visual [Fig. $6 C$; Group $\times \operatorname{Drug}\left(F_{(3,42)}=16.35, p<0.001\right)$, Group $\left(F_{(1,14)}=121.99, p<0.001\right)$, Drug $\left(F_{(3,42)}=16.68, p<\right.$ $0.001)$ ] and olfactory-visual (Fig. 6D; Group $\times$ Drug $\left(F_{(3,45)}=9.63, p<0.01\right)$, Group $\left(F_{(1,15)}=23.91, p<0.001\right)$,
$\left.\operatorname{Drug}\left(F_{(3,45)}=9.97, p<0.001\right)\right]$ MSO task performance. Post hoc independent-samples $t$ tests indicated that ketaminetreated rats were significantly impaired in the ABT/BIC condition compared with saline-treated rats on the tactile-visual $\left(_{(14)}=7.27, p<0.001\right)$ and olfactory-visual $\left(t_{(15)}=4.52, p<\right.$ $0.001)$ MSO tasks, but not different in the ABT-VEH condition $(p>0.05)$. There were no differences in general object exploration (Table 1 ). These results therefore suggest that prefrontal $\alpha_{4} \beta_{2}$ nAChRs reverse the multisensory impairment in ketamine-treated rats by enhancing GABA release. We next probed this potential interaction at the cellular level. 


\section{A Tactile-Visual}

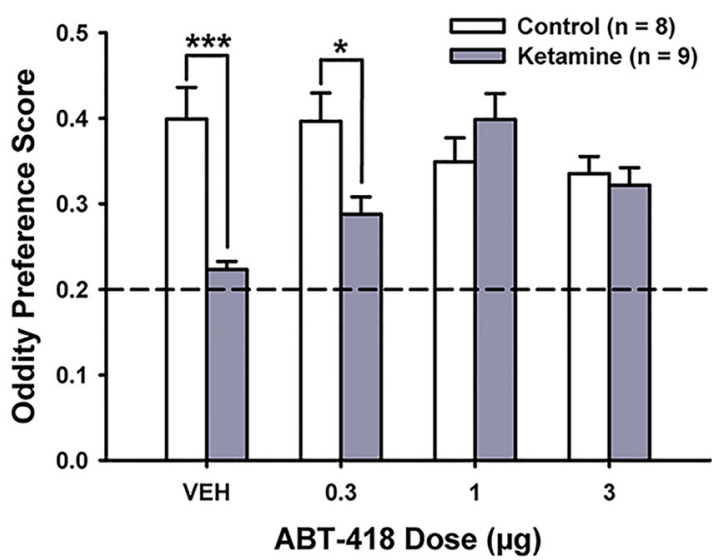

c Tactile-Visual

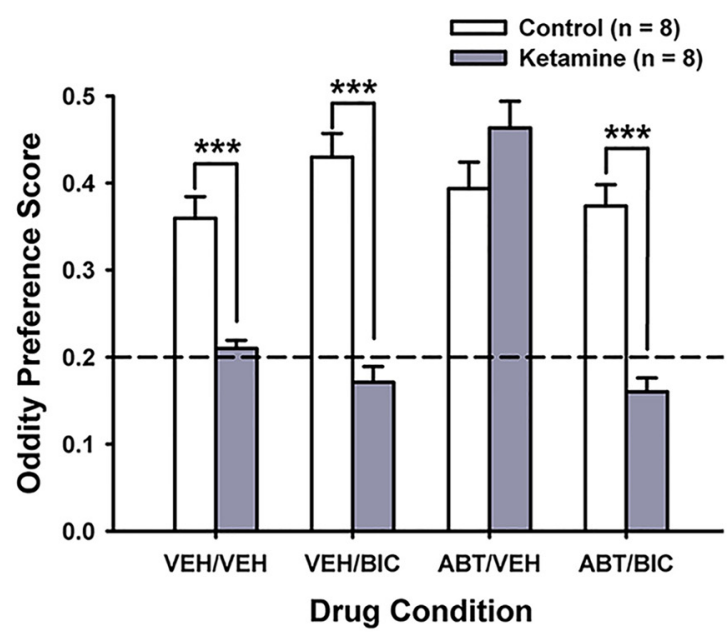

B Olfactory-Visual

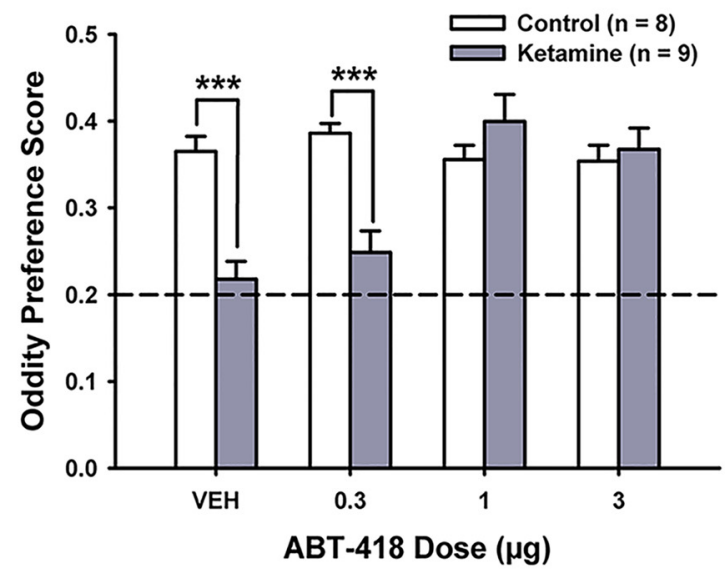

D Olfactory-Visual

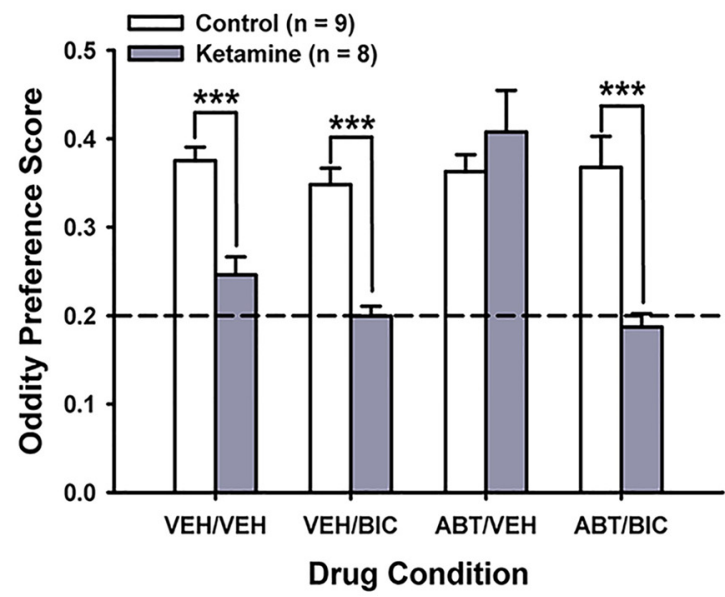

Figure 6. After the $10 \mathrm{~d}$ washout period, ketamine- and saline-treated rats were infused with ABT-418 $(0.3,1$, and $3 \mu \mathrm{g})$ into the $0 \mathrm{FC}$ immediately before testing. Intra-0FC ABT- $418 \mathrm{dose}$ dependently rescued performance of the tactile-visual $(\boldsymbol{A})$ and olfactory-visual $(\boldsymbol{B})$ MSO tasks in ketamine-treated rats. In a separate experiment, ketamine- and saline-treated rats were infused with ABT-418 $(3 \mu \mathrm{g})$ into the OFC immediately before testing and administered the $\mathrm{GABA}_{\mathrm{A}}$ antagonist BIC $(0.5 \mathrm{mg} / \mathrm{kg})$ systemically 20 min before testing. Administration of BIC at a dose that did not affect saline-treated rat performance blocked the ameliorative effect of intra-0FC ABT-418 on performance of the tactile-visual ( $C$ ) and olfactory-visual (D) MS0 tasks in ketamine-treated rats. Oddity preference scores are displayed for group means ( \pm SEM). ${ }^{*} p<0.0125 ;{ }^{* * *} p<0.001$, ketamine versus control rats.

$\boldsymbol{\alpha}_{4} \boldsymbol{\beta}_{2} \mathrm{nAChRs}$ restore GABAergic function in the OFC of ketamine-treated rats

In vitro findings show that rodents chronically administered an NMDA receptor antagonist with a washout period after (tested in a drug-free state) have decreased GABAergic currents in the mPFC (Zhang et al., 2008; Jeevakumar and Kroener, 2016; Kjaerby et al., 2014). In nontreated rodents, activation of $\alpha_{4} \beta_{2}$ nAChRs increases GABAergic currents (Alkondon and Albuquerque, 2001; Couey et al., 2007; Aracri et al., 2010). We assessed GABAergic currents in ketamine-treated (rats: $n=5$; neurons: $n=27$ ) and saline-treated (rats: $n=7$; neurons: $n=31$ ) rats by recording GABAergic sEPSCs in pyramidal neurons located within OFC layer $2 / 3$ at baseline and after the application of $1 \mathrm{~mm}$ $\mathrm{ACh}$ (in the presence of $200 \mathrm{~nm}$ atropine and $10 \mathrm{nM}$ MLA to block muscarinic and $\alpha_{7} \mathrm{ACh}$ receptors, respectively). These pharmacological tools allowed us to probe the interaction between nicotinic and GABAergic signaling using whole-cell electrophys- iology in acute brain slices. Consistent with the literature, we predicted that GABAergic sEPSCs in the brains of ketaminetreated rats would be attenuated and that ACh would return these to control levels.

A mixed-factor ANOVA for the frequency of GABAergic sEPSCs revealed a significant effect of treatment group (Fig. $7 A, C$; ketamine or saline; $\left.F_{(1,56)}=9.18, p<0.01\right)$ and a significant effect of drug application (baseline or ACh; $F_{(1,56)}=31.52, p<$ $0.001)$, but no significant interaction $\left(F_{(1,56)}=0.518, p=0.475\right)$. A planned comparison independent-samples $t$ test indicated that application of ACh restored the frequency of GABAergic sEPSCs in ketamine-treated rats to a level equal to that of saline-treated rats at baseline (Fig. $7 B, C$; saline-baseline vs ketamine-ACh: $\left.t_{(56)}=0.95, p=0.347\right)$. The percentage change in GABAergic sEPSC frequency after ACh application was also significantly higher in ketamine-treated rats (Fig. $7 D ; t_{(56)}=2.51, p<0.05$ ). Furthermore, a mixed-factor ANOVA for the amplitude of 
A

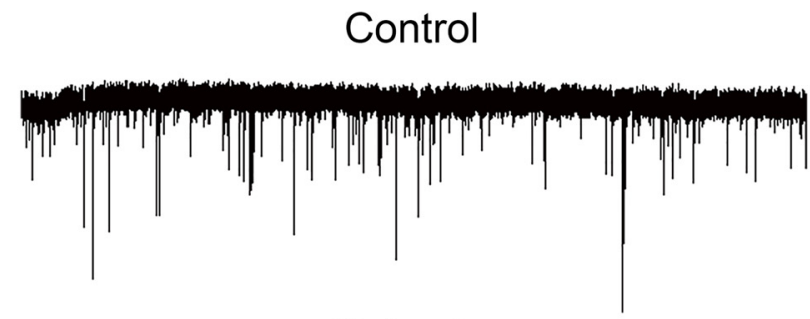

Ketamine

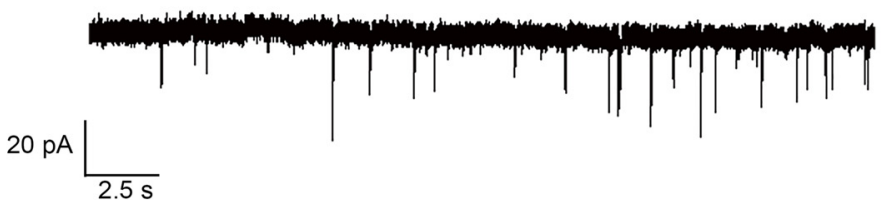

B
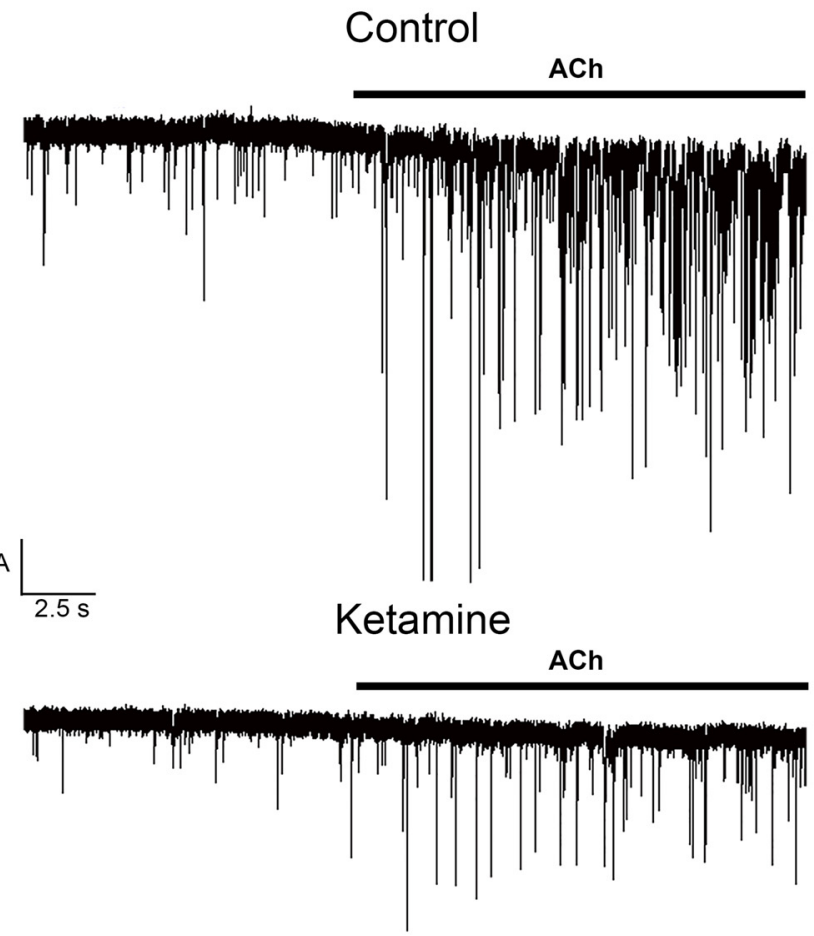

C
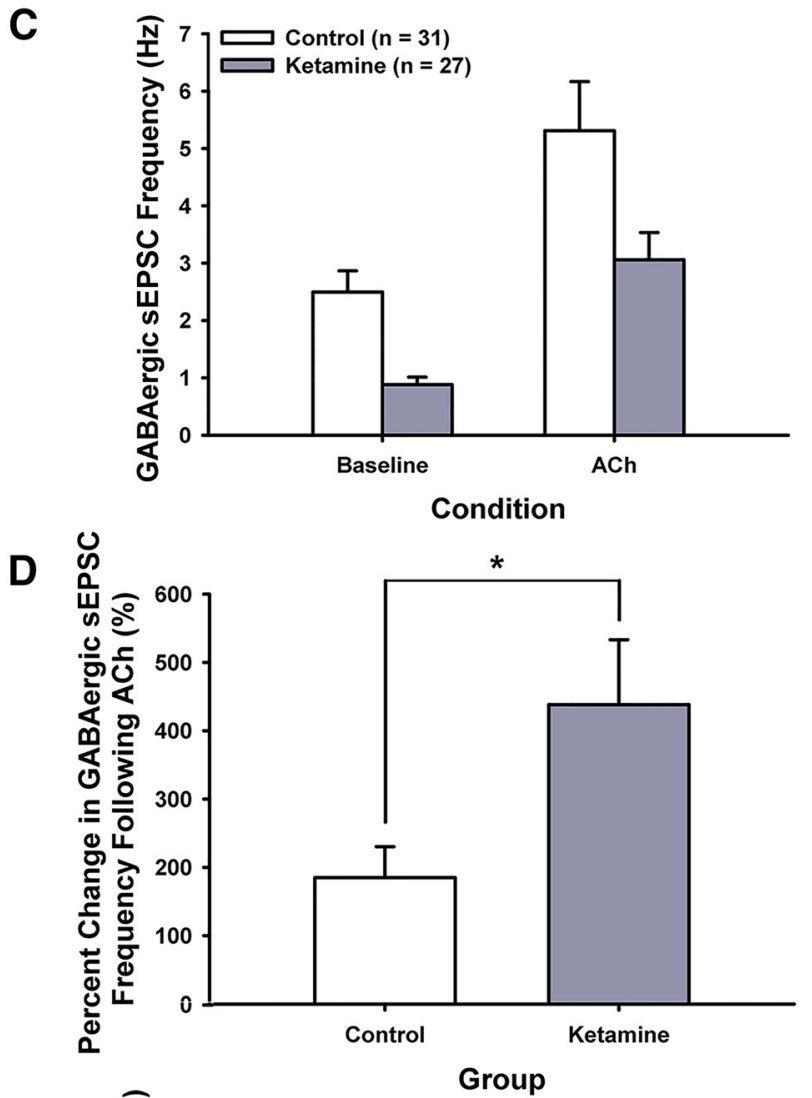

E

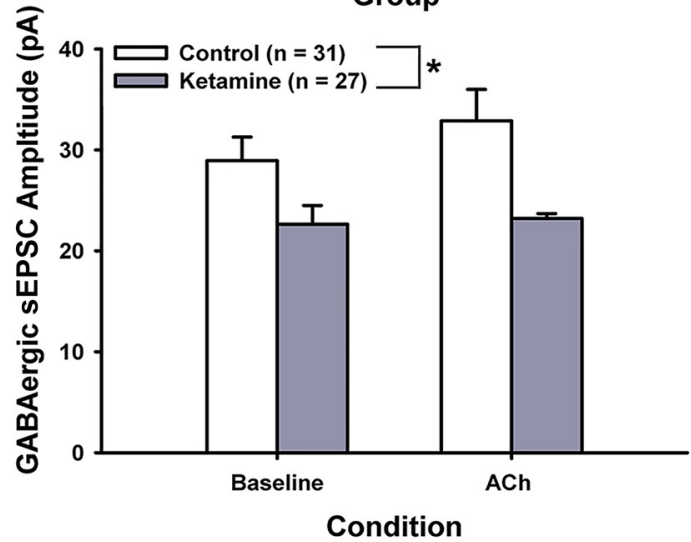

Figure 7. After the $10 \mathrm{~d}$ washout period, ketamine- and saline-treated rats were killed for whole-cell electrophysiology. $A$, Representative traces from pyramidal neurons located within layer $2 / 3$ of rat $0 F$ C showing baseline GABAergic $5 E P S C$ in control and ketamine rats. $B$, Representative traces from pyramidal neurons located within layer $2 / 3$ of rat $0 F C$ showing $G A B A e r g i c s E P S C s$ at baseline and after $1 \mathrm{~mm}$ ACh application (black bar) in control and ketamine rats. C, Frequency of baseline GABAergic sEPSCs was significantly reduced in the OFC of ketamine rats. Application of $1 \mathrm{~mm}$ ACh (in the presence of $200 \mathrm{~nm}$ atropine and $10 \mathrm{~nm} \mathrm{MLA)} \mathrm{restored} \mathrm{GABAergic} \mathrm{sEPSC} \mathrm{frequency} \mathrm{equal} \mathrm{to} \mathrm{that} \mathrm{in} \mathrm{control} \mathrm{rats} \mathrm{at} \mathrm{baseline.} \mathrm{D,} \mathrm{Percentage} \mathrm{change} \mathrm{in} \mathrm{GABAergic} \mathrm{sEPSC} \mathrm{frequency} \mathrm{after} \mathrm{ACh}$ application was significantly higher in ketamine-treated rats. $E$, Amplitude of GABAergic sEPSCs was significantly lower overall in ketamine rats than in control rats (main effect of group: ketamine vs saline, ${ }^{*} p<0.05$ ).

GABAergic sEPSCs revealed a significant treatment group $\left(F_{(1,56)}=6.89, p<0.05\right)$ effect, but no significant interaction $\left(F_{(1,56)}=1.09, p=0.301\right)$ or drug application effect $\left(F_{(1,56)}=\right.$ $1.95, p=0.168$; Fig. $7 E)$. The ability of ACh to increase GABAergic sEPSC frequency in OFC layer $2 / 3$ pyramidal neurons was significantly attenuated by the $\alpha_{4} \beta_{2} \mathrm{nAChR}$ competitive antagonist dihydro- $\beta$-erythroidine ( $\mathrm{DH} \beta \mathrm{E} ; 3 \mu \mathrm{M} ; t_{(5)}=3.07, p=0.028$; ACh: $\mathrm{M}=7.48, \mathrm{SE}=2.52 \mathrm{~Hz}, \mathrm{ACh}+\mathrm{DH} \beta \mathrm{E}: \mathrm{M}=3.26, \mathrm{SE}=$ $1.22 \mathrm{~Hz}$ ). Because DH $\beta E$ did not affect GABAergic sEPSC amplitude $\left(t_{(5)}=0.17, p=0.871\right.$; ACh: $\mathrm{M}=27.19, \mathrm{SE}=5.13 \mathrm{pA}$, $\mathrm{ACh}+\mathrm{DH} \beta \mathrm{E}: \mathrm{M}=26.37, \mathrm{SE}=6.12 \mathrm{pA}$ ), these data suggest that the remediating effects of $\mathrm{ACh}$ are accomplished through $\alpha 4 \beta 2 \mathrm{nAChRs}$ located on GABAergic interneuron presynaptic terminals.

Selective silencing of PV-containing interneurons in the OFC using DREADDs impairs MSO task performance: reversal by $\boldsymbol{\alpha}_{4} \boldsymbol{\beta}_{2} \mathrm{nAChR}$ agonism

Previous findings establish that GABAergic function, and specifically PV expression, is reduced in brains of rodents treated with NMDA receptor antagonists (Behrens et al., 2007; Pratt et al., 2008). In the current study, rats treated with ketamine had reduced expression of $\mathrm{PV}$ in the LO, but not $\mathrm{VO}$, subregion of the OFC compared with saline-treated rats (Fig. 8). A mixed-factor 


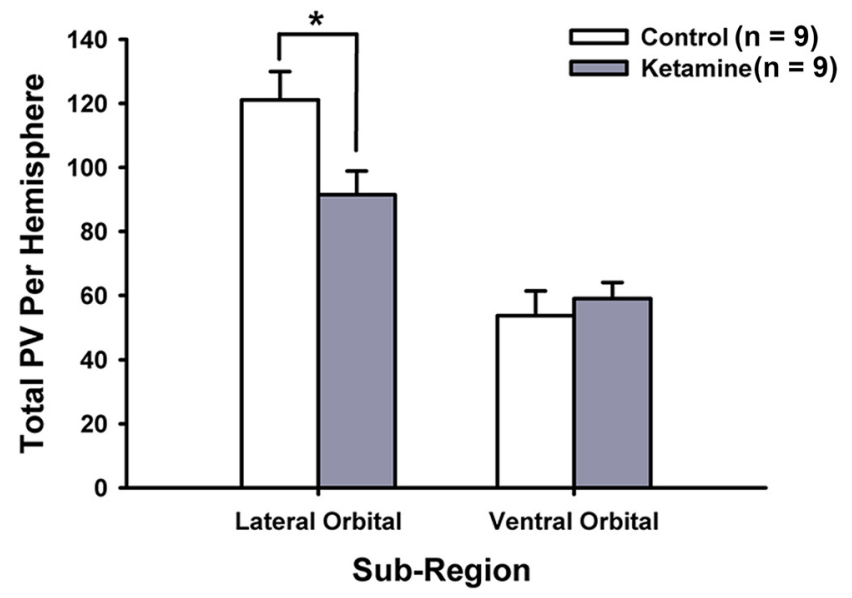

Figure 8. After the $10 \mathrm{~d}$ washout period, ketamine- $(n=5)$ and saline-treated $(n=5)$ rats were killed to examine PV immunoreactivity in the OFC. Total PV counts per hemisphere were significantly decreased in ketamine-treated, but not saline-treated, rats within the LO, but not the V0 OFC. Group means ( \pm SEM) are displayed. ${ }^{*} p<0.05$.

ANOVA revealed a significant interaction $\left(F_{(1,16)}=12.13, p<\right.$ $0.01)$ and main effect of region $\left(F_{(1,16)}=99.22, p<0.001\right)$, but no main effect of group $\left(F_{(1,11)}=1.80, p=0.199\right)$. Post hoc independent-samples $t$ test demonstrated a significant difference in PV expression between ketamine- and saline-treated rats in LO $\left(t_{(16)}=2.57, p<0.05\right)$, but not VO $\left(t_{(16)}=0.57, p=0.575\right)$. We have also shown electrophysiological evidence consistent with these changes. Therefore, we hypothesized that disruption of PVIN activity in the OFC of ketamine-treated rats produces a selective MSO task impairment. To assess the involvement of PVINs in tactile-visual MSO task performance, we silenced the activity of these interneurons directly during behavior using the inhibitory DREADD neuromodulator hM4D. We also investigated the effect of the $\alpha_{4} \beta_{2}$ nAChR agonist ABT-418 on CNOinduced disruption of MSO task performance.

Because this was our first MSO study using mice, we first showed that acute ketamine impaired tactile-visual MSO task performance selectively, sparing tactile- and visual-only oddity performance in mice (Fig. 9A). A repeated-measures ANOVA revealed a significant interaction effect $\left(F_{(2,10)}=19.29, p<\right.$ $0.001)$ and main effect of task $\left(F_{(2,10)}=11.30, p<0.01\right)$, but no significant main effect of drug $\left(F_{(1,5)}=0.78, p=0.418\right)$. Post hoc paired-samples $t$ tests revealed a significant difference between saline and ketamine administration on the tactile-visual oddity task $\left(t_{(5)}=5.96, p<0.001\right)$, but not the unimodal tasks $(p>$ $0.05)$. In addition, $3 \mathrm{mg} / \mathrm{kg}$ of $\mathrm{CNO}$ in wild-type mice did not affect tactile-visual MSO task performance compared with $\mathrm{VEH}$ (paired-samples $t$ test, VEH vs CNO: $t_{(6)}=0.03, p=0.975$; VEH: $\mathrm{M}=0.38, \mathrm{SE}=0.02, \mathrm{CNO}, \mathrm{M}=0.38, \mathrm{SE}=0.01)$.

PV-Cre mice were infused with AAV containing credependent hM4D in the OFC (Fig. 9B, C). Targeting of hM4D in the OFC was selective to PVINs because $73 \%$ of hM4D expressing neurons were positive for PV-ir; coexpression with this method is commonly reported between $80 \%$ and 95\% (Nguyen et al., 2014; Kim et al., 2016) and the $27 \%$ of hM4D-expressing neurons not immunopositive for PV here likely reflects low sensitivity of our PV immunohistochemistry protocol and/or relatively low levels of PV expression in a subpopulation of neurons in OFC. Furthermore, $73 \%$ of the total PV-ir neuron population in the OFC expressed hM4D, demonstrating high efficacy in PVIN transduction (Fig. 9D,E). This experiment used a within-subjects design such that mice were tested on three versions of the oddity task (tactile-only, visual-only, and tactile-visual) and with each of $\mathrm{CNO}$ and $\mathrm{VEH}$ for a total of six trials per mouse; all conditions were counterbalanced. CNO administration in PV-Cre mice impaired tactile-visual MSO task performance selectively compared with $\mathrm{VEH}$ administration, sparing tactile- and visual-only performance [Fig. 9F; Drug $\times$ Task $\left(F_{(2,20)}=27.24, p<0.001\right)$, Drug $\left.\left(F_{(1,10)}=5.26, p<0.05\right), \operatorname{Task}\left(F_{(2,20)}=4.13, p<0.05\right)\right]$. Post hoc paired-samples $t$ tests demonstrated significant differences between $\mathrm{VEH}$ and $\mathrm{CNO}$ infused mice in tactile-visual MSO $\left(t_{(10)}=\right.$ $6.060, p<0.001$ ), but not visual- or tactile-only oddity performance $(p>0.05)$. The analysis of total object exploration revealed a significant main effect of task $\left(F_{(2,20)}=8.69, p<0.01\right)$, but no significant interaction or main effect of drug. Exploration was significantly lower in the visual-only task $(p<0.01)$; however, task performance was not affected by this lower exploration (Table 2).

Administration of the $\alpha_{4} \beta_{2}$ nAChR agonist ABT-418 (0.2 mg/ $\mathrm{kg})$ in $\mathrm{PV}$-Cre mice reversed the $\mathrm{CNO}$-induced $\mathrm{MSO}$ impairment [Fig. $9 G ; 2 \times 2$ ANOVA: $\operatorname{ABT} \times \operatorname{CNO}\left(F_{(1,10)}=10.54, p<0.01\right)$, $\left.\operatorname{ABT}\left(F_{(1,10)}=14.58, p<0.01\right), \mathrm{CNO}\left(F_{(1,10)}=17.49, p<0.01\right)\right]$. Post hoc paired-samples $t$ tests demonstrated a significant difference between $\mathrm{CNO} / \mathrm{VEH}$ and $\mathrm{VEH} / \mathrm{VEH}\left(t_{(10)}=6.91, p<\right.$ 0.001 ), as well as $\mathrm{CNO} / \mathrm{VEH}$ and $\mathrm{ABT} / \mathrm{CNO}\left(t_{(10)}=10.46, p<\right.$ 0.001 ). There were no differences in object exploration (Table 2).

We verified the ability of hM4D to inhibit the excitability of PVINs in the OFC of PV-Cre mice and for ACh to reverse this inhibition [Fig. 9H,I; repeated-measures one-way ANOVA, $\left.F_{(2,10)}=5.649, p=0.02(n=6)\right]$. In PVINs expressing hM4D, the number of action potentials elicited in response to $500 \mathrm{~ms}$ injection of $120 \mathrm{pA}$ was reduced from $19.0 \pm 3.1$ at baseline to $10.8 \pm$ 3.5 after 5 min application of $1 \mu \mathrm{M} \mathrm{CNO}$ (Bonferroni post hoc test, $p=0.02)$. In the continuing presence of $1 \mu \mathrm{M} \mathrm{CNO}$, the selective activation of $\alpha_{4} \beta_{2} \mathrm{nAChRs}$ through the application of $1 \mathrm{~mm} \mathrm{ACh}$ (in the presence of $200 \mathrm{~nm}$ atropine and $10 \mathrm{~nm}$ MLA) returned excitability to near-baseline levels (17.8 \pm 3.6 action potentials; $p=1.0$ compared with baseline).

\section{Discussion}

Using a novel multisensory object oddity task, the current study demonstrates that ketamine-treated rats, a recognized model of schizophrenia, display a selective multisensory impairment that generalizes across different combinations of sensory modalities. Agonism of OFC $\alpha_{4} \beta_{2}$ nAChRs reversed the multisensory impairment. The remediating effect of prefrontal $\mathrm{nAChR}$ activation in ketaminetreated rats was blocked by antagonism of $\mathrm{GABA}_{\mathrm{A}}$ receptors. Therefore, we hypothesized that decreased GABAergic function in the OFC of ketamine-treated rats was linked to impaired MSO performance and activation of presynaptic $n A C h R s$ restored this deficit by enhancing GABA release. In support of this notion, our electrophysiological findings suggest that GABA release onto pyramidal neurons in the OFC of ketamine-treated rats is significantly decreased and this can be restored to the level of saline-treated rats at baseline by activating presynaptic $\alpha_{4} \beta_{2}$ nAChRs on GABAergic interneurons. Expression of PV, a marker for a subtype of GABAergic interneurons, was also significantly decreased in the OFC of ketaminetreated rats, linking this GABAergic interneuron type to the MSO task deficit reported here. Finally, pharmacogenetic inhibition of PVINs in the OFC of PV-Cre mice using DREADDs revealed a selective MSO task impairment that was reversed by administration of the selective $\alpha_{4} \beta_{2}$ nAChR agonist ABT-418. We verified in brain slices using electrophysiology that $\mathrm{CNO}$-induced inhibition of PVINs was reversed by activation of $\alpha_{4} \beta_{2} \mathrm{nAChRs,} \mathrm{supporting} \mathrm{our}$ behavioral results. The present findings therefore provide conver- 
A

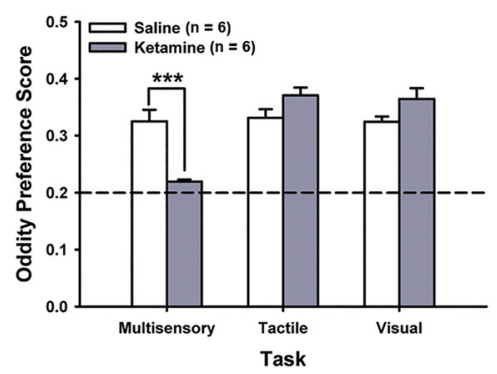

D
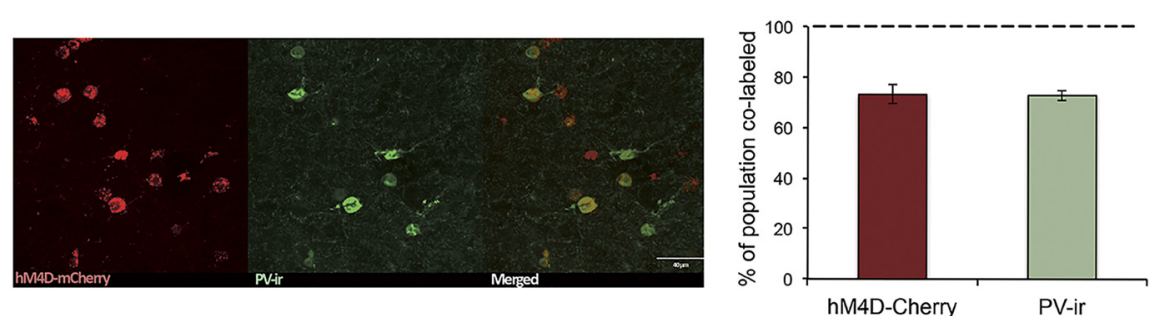

G

H

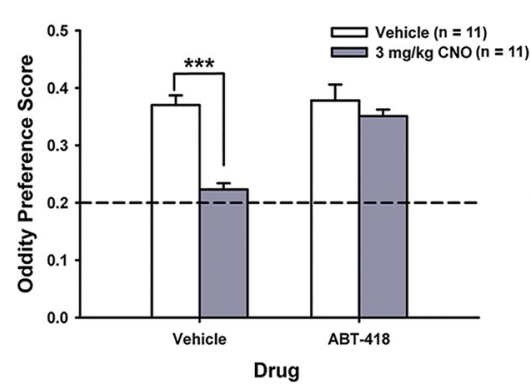

E

B

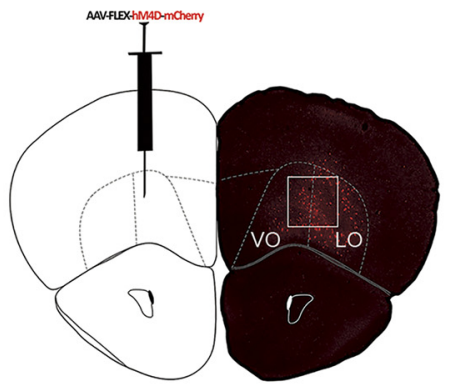

C

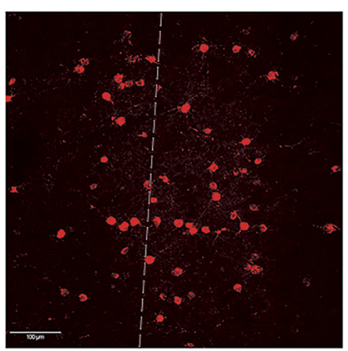

F

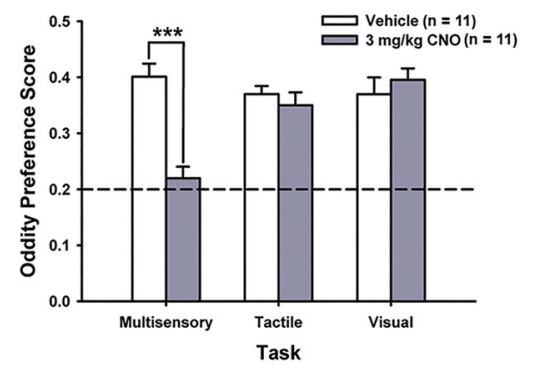

I
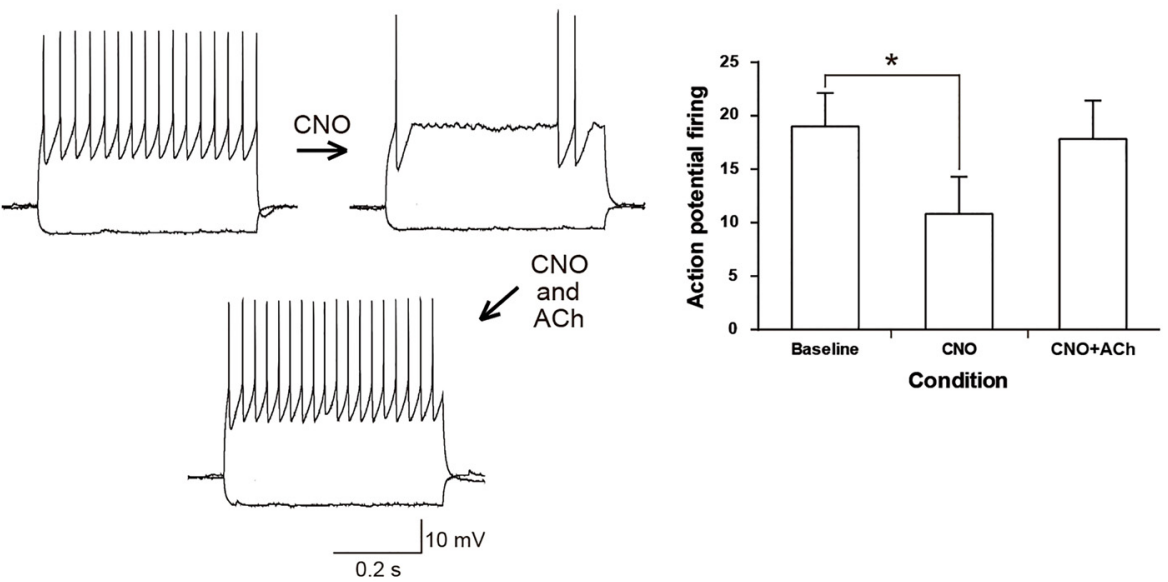

Figure 9. A, Systemic administration of ketamine $(20 \mathrm{mg} / \mathrm{kg})$ in wild-type mice $(n=6)$ selectively impaired tactile-visual MSO task performance, sparing tactile- and visual-only unimodal oddity task performance. $\boldsymbol{B}$, Representative image of hM4D-mCherry expression in the OFC of a PV-Cre mouse overlaid on a section from the Paxinos and Franklin (2007) mouse brain atlas (bregma $+2.6 \mathrm{~mm})$. Dashed lines indicate the boundaries of the OFC. AAV $(0.3 \mu \mathrm{l})$ was infused into the OFC bilaterally $\sim 2$ weeks before behavioral testing. hM4D-mCherry expression was observed consistently within the ventral and lateral OFC with minimal spread to adjacent areas. C, Confocal image (20× magnification) of boxed area in $\boldsymbol{B}$. D, Representative confocal images (40X) of $m$ Cherry expression (left), PV-ir (middle), and merged images (right) from OFC of a PV-Cre mouse administered the hM4D AAV. E, Percentage of cells (mean \pm SEM) double labeled for hM4D-mCherry and PV-ir in PV-Cre mice infused with hM4D AAV $(n=6)$. Red bar indicates that $\sim 72 \%$ of hM4D-mCherry expressing cells were also immunopositive for PV. Green bar shows that $\sim 73 \%$ of PV-immunopositive cells also expressed hM4D-mCherry. $\boldsymbol{F}$, PV-INs were pharmacogenetically silenced in the OFC of PV-Cre mice $(n=11)$. Both experiments were within subjects. Administration of $\mathrm{CNO}$ ( $3 \mathrm{mg} / \mathrm{kg}$ ) 15 min before testing selectively impaired tactile-visual MSO task performance, sparing tactile- and visual-only unimodal oddity performance in PV-Cre mice. $G$, Systemic coadministration of ABT-418 $(0.2 \mathrm{mg} / \mathrm{kg})$ with CNO rescued tactile-visual MSO performance in PV-Cre mice. $\boldsymbol{H}$, Representative traces from hM4D-mCherry-expressing cells showing action potentials elicited by the injection of $120 \mathrm{pA}$ current at baseline, after 5 min application of $1 \mu \mathrm{M} C \mathrm{~N}$, and after application of $1 \mathrm{~mm}$ ACh in the continued presence of $1 \mu \mathrm{m}$ CNO. All recordings were collected in the presence of $200 \mathrm{~nm}$ atropine and $10 \mathrm{~nm}$ MLA. I, Number of baseline action potentials was significantly reduced after application of CNO and this was restored to near baseline after application of ACh in the presence of $\mathrm{CNO}(n=6)$. Dashed line represents chance oddity preference score. Oddity preference scores are displayed for group means $( \pm S E M) .{ }^{*} p<0.05$; ${ }^{* * *} p<0.01$, ketamine versus saline or CNO versus VEH.

gent evidence for a mechanism by which presynaptic nAChRs ameliorate the MSO task impairment in ketamine-treated rats by restoring GABAergic transmission in the OFC.

\section{Generalized multisensory impairment in a rodent model of schizophrenia}

The selective MSO task impairment in ketamine-treated rats supports and extends our previous findings showing that treated rats display a selective tactile-to-visual CMOR deficit (Jacklin et al., 2012;
Cloke and Winters, 2015). Importantly, the current study demonstrates that multisensory deficits in ketamine-treated rats are generalizable to modality combinations (e.g., olfactory-visual) beyond tactile-visual and that this impairment is seen with negligible memory demands. The MSO task represents a substantial advance over other multisensory tasks for rodents (Botly and De Rosa, 2007; Winters and Reid, 2010) in terms of its relative simplicity and absence of learning and memory components. The multisensory facilitation task for humans (Williams et al., 2010; Stone et al., 2011), which has 
Table 2. Control measures collected from mouse oddity experiments for each condition

\begin{tabular}{lll}
\hline Experiment & Condition & $\begin{array}{c}\text { Total object } \\
\text { exploration }\end{array}$ \\
\hline TAC-VIS MSO + controls (TAC and VIS only): & VEH (TAC-VIS) & $14.35 \pm 1.29$ \\
systemic ketamine in wildtype mice & VEH (TAC) & $23.02 \pm 3.77$ \\
& VEH (VIS) & $11.57 \pm 1.28$ \\
& KET (TAC-VIS) & $20.70 \pm 1.32$ \\
& KET (TAC) & $26.80 \pm 3.17$ \\
& KET (VIS) & $15.31 \pm 1.52$ \\
TAC-VIS MSO: CN0 in wildtype mice & VEH & $9.45 \pm 1.80$ \\
& CNO & $6.96 \pm 1.36$ \\
TAC-VIS MSO + controls (TAC and VIS only): & VEH (TAC-VIS) & $24.15 \pm 1.92$ \\
systemic CNO in PV-Cre mice & VEH (TAC) & $24.18 \pm 1.60$ \\
& VEH (VIS) & $19.14 \pm 2.14$ \\
& CNO (TAC-VIS) & $27.37 \pm 2.65$ \\
& CNO (TAC) & $23.88 \pm 1.67$ \\
TAC-VIS MSO: systemic CNO + systemic & CNO (VIS) & $17.17 \pm 1.33$ \\
ABT-418 in PV-Cre mice & VEH/VEH & $16.46 \pm 1.63$ \\
& VEH/ABT & $15.49 \pm 2.12$ \\
& CNO/VEH & $19.31 \pm 1.70$ \\
& CNO/ABT & $17.34 \pm 2.23$ \\
\hline
\end{tabular}

Data are expressed as the mean \pm SEM of the total time in seconds spent exploring the objects.

KET, Ketamine; TAC, tactile; VIS, visual.

been used to uncover atypical multisensory integration in schizophrenia, suggests a basic impairment at the level of multisensory perceptual processing and our present results with this novel task are consistent with this interpretation.

\section{Prefrontal $\alpha_{4} \beta_{2}$ nAChRs restore multisensory oddity performance in ketamine-treated rats}

Administration of nicotine improves cognition in schizophrenia patients and rodent models (Smith et al., 2006; Barr et al., 2008; Hashimoto et al., 2008; Wildeboer and Stevens, 2008; Rushforth et al., 2011; Lieberman et al., 2013). Accordingly, MSO task performance was rescued by administration of nicotine and an $\alpha_{4} \beta_{2}$ $\mathrm{nAChR}$ agonist in the OFC of ketamine-treated rats. These findings extend our previous results with the CMOR task (Jacklin et al., 2012; Cloke and Winters, 2015), demonstrating the generalizability of this nicotinic effect to a different multisensory task and multiple sensory modality combinations. Furthermore, the effect of $\mathrm{nAChR}$ agonism was receptor and region specific as the selective $\alpha_{7}$ nAChR agonist GTS-21 and intra-mPFC nicotine failed to restore MSO task performance in ketamine-treated rats.

\section{GABAergic-nAChR mechanism restores multisensory oddity performance in ketamine-treated rats}

A primary goal of the current study was to elucidate the mechanism underlying restoration of MSO task performance in ketamine-treated rats by $\alpha_{4} \beta_{2}$ nAChR activation in the OFC. The remediating effect of intra-OFC ABT- 418 was blocked by $\mathrm{GABA}_{\mathrm{A}}$ receptor antagonism, replicating our previous findings with CMOR (Cloke and Winters, 2015). GABAergic function is severely affected in patients and rodents treated with NMDA receptor antagonists, specifically in the PFC (Lewis et al., 2005; Behrens et al., 2007; Pratt et al., 2008; Lewis et al., 2012). Our electrophysiological findings demonstrated that GABAergic currents were significantly reduced in the OFC of ketamine-treated rats. Activation of pharmacologically isolated $\alpha_{4} \beta_{2}$ nAChRs in the OFC restored inhibitory currents without affecting GABAergic amplitude, suggesting that presynaptic $\alpha_{4} \beta_{2}$ nAChRs rescued GABAergic function. $\alpha_{4} \beta_{2}$ nAChRs have been shown to be localized presynaptically on GABAergic interneurons (Porter et al., 1999;
Gulledge et al., 2007) and to enhance inhibitory currents (Alkondon and Albuquerque, 2001; Couey et al., 2007; Aracri et al., 2010). Moreover, chronic ketamine administration in rodents upregulates nAChR expression in the cortex (Chatterjee et al., 2012), potentially explaining why nAChRs have greater efficacy in restoring MSO performance and increasing GABAergic currents in ketamine-treated rats compared with saline-treated rats. These findings reinforce our behavioral findings, suggesting that an optimal level of GABAergic function in the OFC is required for MSO task performance and that $\alpha_{4} \beta_{2}$ nAChR activation restores this essential inhibitory transmission in ketamine-treated rats.

Markers of PV are decreased in PFC of schizophrenia patients and rodents treated with NMDA receptor antagonists (Lewis et al., 2005; Behrens et al., 2007; Pratt et al., 2008; Lewis et al., 2012). Our treatment regimen with ketamine reduced PV-ir significantly in the OFC, replicating previous studies (Thomsen et al., 2010; Romon et al., 2011). This provides further support for a link between disrupted PVIN function due to NMDA receptor hypofunction (Lisman et al., 2008) that may influence cognition (Korotkova et al., 2010; Carlén et al., 2012). Recently, Gogolla et al. (2014) showed using in vivo imaging that decreased markers of PV are associated with impaired multisensory integration; this deficit was reversed by pharmacologically restoring PV levels, suggesting that PVINs are crucial for multisensory integration. We report that inhibition of PVINs using PV-Cre mice infused with inhibitory DREADD hM4D in the OFC impaired MSO task performance, mirroring our findings with ketamine-treated rats. This is the first evidence to our knowledge that direct inhibition of PVINs induces impairment in multisensory integration.

Surprisingly, systemic administration of ABT-418 in mice restored the deficit induced by PVIN inhibition. The $\alpha_{4}$ nicotinic subunit has been shown to be colocalized on PVINs in the cortex of mice (Aracri et al., 2010), rats (Liu et al., 2005; Dehkordi et al., 2007), and humans (Krenz et al., 2001) and cholinergic projections from the basal forebrain innervate PVINs in the rat cortex (Henny and Jones, 2008). Using whole-cell electrophysiology, we established that $\mathrm{CNO}$-induced inhibition of PV-INs was reversed by activation of $\alpha_{4} \beta_{2} \mathrm{nAChRs}$. Therefore, it is likely, given our other results, that ABT-418 stimulates GABA release from PVINs to restore MSO task performance. However, nAChRs are also found on other GABAergic interneurons (Porter et al., 1999; Gulledge et al., 2007) and we cannot conclude from the current data which specific GABAergic interneuron nAChRs stimulate in the OFC. Future studies will aim to target nAChRs specifically on PVINs. The present findings nonetheless strongly suggest that dysfunction of PVINs in the OFC of ketamine-treated rats impairs multisensory integration and that this ability can be restored by activation of $\alpha_{4} \beta_{2}$ nAChRs, which "normalize" prefrontal inhibitory transmission.

\section{Conclusion}

The current study reveals in ketamine-treated rats a generalized multisensory integration impairment, the nature of which appears to be independent of memory function and basic perceptual processing. Schizophrenia patients display multisensory deficits at the level of perceptual binding (Williams et al., 2010; Stone et al., 2011; Tseng et al., 2015) and the novel MSO task provides a simple and robust method for assessing similar functions in rodents and preclinical models (Butler et al., 2008). Our results strongly suggest that nAChRs-specifically $\alpha_{4} \beta_{2}$ nAChRs - can restore impaired GABAergic transmission within the OFC of ketamine-treated rats to facilitate multisensory integration. We also identify PVINs as a likely target of ketamine- 
mediated disruption, consistent with findings from animal models and schizophrenia patients (Lewis et al., 2005; Behrens et al., 2007; Homayoun and Moghaddam, 2008; Pratt et al., 2008; Zhang et al., 2008; Lewis et al., 2012; Jeevakumar and Kroener, 2016; Kjaerby et al., 2014). Future pharmacological therapies targeting the GABAergic system and/or GABAergic-nicotinic interactions may show promise in treating specific aspects of cognition in schizophrenia (Menzies et al., 2007; Damgaard et al., 2011).

\section{References}

Alkondon M, Albuquerque EX (2001) Nicotinic acetylcholine receptor $\alpha 7$ and $\alpha 4 \beta 2$ subtypes differentially control GABAergic input to CA1 Neurons in rat hippocampus. J Neurophysiol 86:3043-3055. Medline

Aracri P, Consonni S, Morini R, Perrella M, Rodighiero S, Amadeo A, Becchetti A (2010) Tonic modulation of GABA release by nicotinic acetylcholine receptors in layer $\mathrm{V}$ of the murine prefrontal cortex. Cereb Cortex 20:1539-1555. CrossRef Medline

Bailey CD, De Biasi M, Fletcher PJ, Lambe EK (2010) The nicotinic acetylcholine receptor $\alpha 5$ subunit plays a key role in attention circuitry and accuracy. J Neurosci 30:9241-9252. CrossRef Medline

Barr RS, Culhane MA, Jubelt LE, Mufti RS, Dyer MA, Weiss AP, Deckersbach T, Kelly JF, Freudenreich O, Goff DC, Evins AE (2008) The effects of transdermal nicotine on cognition in nonsmokers with schizophrenia and nonpsychiatric controls. Neuropsychopharmacology 33:480490. CrossRef Medline

Bartko SJ, Winters BD, Cowell RA, Saksida LM, Bussey TJ (2007) Perirhinal cortex resolves feature ambiguity in configural object recognition and perceptual oddity tasks. Learn Mem 14:821-832. CrossRef

Behrens MM, Ali SS, Dao DN, Lucero J, Shekhtman G, Quick KL, Dugan LL (2007) Ketamine-induced loss of phenotype of fast-spiking interneurons is mediated by NADPH-oxidase. Science 318:1645-1647. CrossRef Medline

Bellani M, Cerruti S, Brambilla P, Bellani M, Cerruti S, Brambilla P (2010) Orbitofrontal cortex abnormalities in schizophrenia. Epidemiol Psychiatr Soc 19:23-25. Medline

Botly LC, De Rosa E (2007) Cholinergic influences on feature binding. Behav Neurosci 121:264-276. CrossRef Medline

Butler PD, Silverstein SM, Dakin SC (2008) Visual perception and its impairment in schizophrenia. Biol Psychiatry 64:40-47. CrossRef Medline

Carlén M, Meletis K, Siegle JH, Cardin JA, Futai K, Vierling-Claassen D, Rühlmann C, Jones SR, Deisseroth K, Sheng M, Moore CI, Tsai LH (2012) A critical role for NMDA receptors in parvalbumin interneurons for gamma rhythm induction and behavior. Mol Psychiatry 17:537-548. CrossRef Medline

Chatterjee M, Verma R, Ganguly S, Palit G (2012) Neurochemical and molecular characterization of ketamine-induced experimental psychosis model in mice. Neuropharmacology 63:1161-1171. CrossRef Medline

Cloke JM, Winters BD (2015) $\alpha 4 \beta 2$ Nicotinic receptor stimulation of the GABAergic system within the orbitofrontal cortex ameliorates the severe crossmodal object recognition impairment in ketamine-treated rats: implications for cognitive dysfunction in schizophrenia. Neuropharmacology 90:42-52. CrossRef Medline

Couey JJ, Meredith RM, Spijker S, Poorthuis RB, Smit AB, Brussaard AB, Mansvelder HD (2007) Distributed network actions by nicotine increase the threshold for spike-timing-dependent plasticity in prefrontal cortex. Neuron 54:73-87. CrossRef Medline

Courtin J, Chaudun F, Rozeske RR, Karalis N, Gonzalez-Campo C, Wurtz H, Abdi A, Baufreton J, Bienvenu TC, Herry C (2014) Prefrontal parvalbumin interneurons shape neuronal activity to drive fear expression. Nature 505:92-96. CrossRef Medline

Damgaard T, Plath N, Neill JC, Hansen SL (2011) Extrasynaptic GABAA receptor activation reverses recognition memory deficits in an animal model of schizophrenia. Psychopharmacology 214:403-413. CrossRef Medline

Dehkordi O, Millis RM, Dennis GC, Jazini E, Williams C, Hussain D, JayamTrouth A (2007) Expression of alpha-7 and alpha-4 nicotinic acetylcholine receptors by GABAergic neurons of rostral ventral medulla and caudal pons. Brain Res 1185:95-102. CrossRef Medline

Eryilmaz H, Tanner AS, Ho NF, Nitenson AZ, Silverstein NJ, Petruzzi LJ, Goff DC, Manoach DS, Roffman JL (2016) Disrupted working memory cir- cuitry in schizophrenia: disentangling fMRI markers of core pathology vs other aspects of impaired performance. Neuropsychopharmacology 41: 2411-2420. CrossRef Medline

Fuster J (1997) The prefrontal cortex-anatomy, physiology, and neuropsychology of the frontal lobe. Philadelphia: Lippincott-Raven.

Fuster JM, Bodner M, Kroger JK (2000) Cross-modal and cross-temporal association in neurons of frontal cortex. Nature 405:347-351. CrossRef Medline

Gogolla N, Takesian AE, Feng G, Fagiolini M, Hensch TK (2014) Sensory integration in mouse insular cortex reflects GABA circuit maturation. Neuron 83:894-905. CrossRef Medline

Green MF, Kern RS, Heaton RK (2004) Longitudinal studies of cognition and functional outcome in schizophrenia: implications for MATRICS. Schizophr Res 72:41-51. CrossRef Medline

Gulledge AT, Park SB, Kawaguchi Y, Stuart GJ (2007) Heterogeneity of phasic cholinergic signaling in neocortical neurons. J Neurophysiol 97:22152229. CrossRef Medline

Hashimoto K, Ishima T, Fujita Y, Matsuo M, Kobashi T, Takahagi M, Tsukada H, Iyo M (2008) Phencyclidine-induced cognitive deficits in mice are improved by subsequent subchronic administration of the novel selective $\alpha 7$ nicotinic receptor agonist SSR180711. Biol Psychiatry 63:9297. CrossRef Medline

Henny P, Jones BE (2008) Projections from basal forebrain to prefrontal cortex comprise cholinergic, GABAergic and glutamatergic inputs to pyramidal cells or interneurons. Eur J Neurosci 27:654-670. CrossRef Medline

Homayoun H, Moghaddam B (2008) Orbitofrontal cortex neurons as a common target for classic and glutamatergic antipsychotic drugs. Proc Natl Acad Sci U S A 105:18041-18046. CrossRef Medline

Jacklin DL, Goel A, Clementino KJ, Hall AW, Talpos JC, Winters BD (2012) Severe cross-modal object recognition deficits in rats treated subchronically with NMDA receptor antagonists are reversed by systemic nicotine: implications for abnormal multisensory integration in schizophrenia. Neuropsychopharmacology 37:2322-2331. CrossRef Medline

Jeevakumar V, Kroener S (2016) Ketamine administration during the second postnatal week alters synaptic properties of fast-spiking interneurons in the medial prefrontal cortex of adult mice. Cereb Cortex 26:1117-1129. CrossRef Medline

Jentsch JD, Roth RH (1999) The neuropsychopharmacology of phencyclidine: from NMDA receptor hypofunction to the dopamine hypothesis of schizophrenia. Neuropsychopharmacology 20:201-225. CrossRef Medline

Kanahara N, Sekine Y, Haraguchi T, Uchida Y, Hashimoto K, Shimizu E, Iyo M (2013) Orbitofrontal cortex abnormality and deficit schizophrenia. Schizophr Res 143:246-252. CrossRef Medline

Kim H, Ährlund-Richter S, Wang X, Deisseroth K, Carlén M (2016) Prefrontal parvalbumin neurons in control of attention. Cell 164:208-218. CrossRef Medline

Kjaerby C, Broberg BV, Kristiansen U, Dalby NO (2014) Impaired GABAergic inhibition in the prefrontal cortex of early postnatal phencyclidine (PCP)-treated rats. Cereb Cortex 24:2522-2532. CrossRef Medline

Korotkova T, Fuchs EC, Ponomarenko A, von Engelhardt J, Monyer H (2010) NMDA receptor ablation on parvalbumin-positive interneurons impairs hippocampal synchrony, spatial representations, and working memory. Neuron 68:557-569. CrossRef Medline

${ }^{\star}$ Krashes MJ, Koda S, Ye C, Rogan SC, Adams AC, Cusher DS, Maratos-Flier E, Roth BL, Lowell BB (2011) Rapid, reversible activation of AgRP neurons drive feeding behavior in mice. J Clin Invest 121:1424-1428. CrossRef Medline

Krenz I, Kalkan D, Wevers A, de Vos RA, Steur EN, Lindstrom J, Pilz K, Nowacki S, Schütz U, Moser N, Witter B, Schröder H (2001) Parvalbumin-containing interneurons of the human cerebral cortex express nicotinic acetylcholine receptor proteins. J Chem Neuroanat 21: 239-246. CrossRef Medline

Lewis DA, Hashimoto T, Volk DW (2005) Cortical inhibitory neurons and schizophrenia. Nat Rev Neurosci 6:312-324. CrossRef Medline

Lewis DA, Curley AA, Glausier JR, Volk DW (2012) Cortical parvalbumin interneurons and cognitive dysfunction in schizophrenia. Trends Neurosci 35:57-67. CrossRef Medline

Lieberman JA, Dunbar G, Segreti AC, Girgis RR, Seoane F, Beaver JS, Duan N, Hosford DA (2013) A randomized exploratory trial of an $\alpha$-7 nicotinic receptor agonist (TC-5619) for cognitive enhancement in schizophrenia. Neuropsychopharmacology 38:968-975. CrossRef Medline 
Lipton PA, Alvarez P, Eichenbaum H (1999) Crossmodal associative memory representations in rodent orbitofrontal cortex. Neuron 22:349-359. CrossRef Medline

Lisman JE, Coyle JT, Green RW, Javitt DC, Benes FM, Heckers S, Grace AA (2008) Circuit-based framework for understanding neurotransmitter and risk gene interactions in schizophrenia. Trends Neurosci 31:234-242. CrossRef Medline

Liu JJ, Mohila CA, Gong Y, Govindarajan N, Onn SP (2005) Chronic nicotine exposure during adolescence differentially influences calcium-binding proteins in rat anterior cingulate cortex. Eur J Neurosci 22:2462-2474. CrossRef Medline

Marutle A, Zhang X, Court J, Piggott M, Johnson M, Perry R, Perry E, Nordberg A (2001) Laminar distribution of nicotinic receptor subtypes in cortical regions in schizophrenia. J Chem Neuroanat 22:115-126. CrossRef Medline

Menzies L, Ooi C, Kamath S, Suckling J, McKenna P, Fletcher P, Bullmore E, Stephenson C (2007) Effects of gamma-aminobutyric acid-modulating drugs on working memory and brain function in patients with schizophrenia. Arch Gen Psychiatry 64:156-167. CrossRef Medline

Murray AJ, Sauer JF, Riedel G, McClure C, Ansel L, Cheyne L, Bartos M, Wisden W, Wulff P (2011) Parvalbumin-positive CA1 interneurons are required for spatial working but not for reference memory. Nat Neurosci 14:297-299. CrossRef Medline

Nguyen R, Morrissey MD, Mahadevan V, Cajanding JD, Woodin MA, Yeomans JS, Takehara-Nishiuchi K, Kim JC (2014) Parvalbumin and GAD65 interneuron inhibition in the ventral hippocampus induces distinct behavioral deficits relevant to schizophrenia. J Neurosci 34:1494814960. CrossRef Medline

Olcese U, Iurilli G, Medini P (2013) Cellular and synaptic architecture of multisensory integration in the mouse neocortex. Neuron 79:579-593. CrossRef Medline

Olney JW, Newcomer JW, Farber NB (1999) NMDA receptor hypofunction model of schizophrenia. J Psychiatr Res 33:523-533. CrossRef Medline

Ongür D, Price J (2000) The organization of network within the orbital and medial prefrontal cortex of rats, monkeys and humans. Cereb Cortex 10:206-219. CrossRef Medline

Paxinos G, Franklin K (2007) The mouse brain in stereotaxic coordinates, 2nd ed. New York, NY: Academic Press.

Paxinos G, Watson C (2005) The rat brain in stereotaxic coordinates, 5th ed. New York, NY: Academic Press.

Porter JT, Cauli B, Tsuzuki K, Lambolez B, Rossier J, Audinat E (1999) Selective excitation of subtypes of neocortical interneurons by nicotinic receptors. J Neurosci 19:5228-5235. Medline

Pratt J, Winchester C, Egerton A, Cochran SM, Morris BJ (2008) Modelling prefrontal cortex deficits in schizophrenia: implications for treatment. Br J Pharmacol 153 S465-S470.
Reid J, Jacklin D, Winters B (2014) Delineating prefrontal cortex region contributions to crossmodal object recognition in rats. Cereb Cortex 24: 2108-2119. CrossRef Medline

Romon T, Mengod G, Adell A (2011) Expression of parvalbumin and glutamic acid decarboxylase-67 after acute administration of MK-801. Implications for the NMDA hypofunction model of schizophrenia. Psychopharmacology (Berl) 217:231-238. CrossRef Medline

Rushforth SL, Steckler T, Shoaib M (2011) Nicotine improves working memory span capacity in rats following sub-chronic ketamine exposure. Neuropsychopharmacology 36:2774-2781. CrossRef Medline

Shenton ME, Dickey CC, Frumin M, McCarley RW (2001) A review of MRI findings in schizophrenia. Schizophr Res 49:1-52. Medline

Smith RC, Warner-Cohen J, Matute M, Butler E, Kelly E, Vaidhyanathaswamy S, Khan A (2006) Effects of nicotine nasal spray on cognitive function in schizophrenia. Neuropsychopharmacology 31:637-643. CrossRef Medline

Stone DB, Urrea LJ, Aine CJ, Bustillo JR, Clark VP, Stephen JM (2011) Unisensory processing and multisensory integration in schizophrenia: a highdensity electrical mapping study. Neuropsychologia 49:3178-3187. CrossRef Medline

Thomsen MS, Hansen HH, Mikkelsen JD (2010) $\alpha 7$ nicotinic receptor agonism mitigates phencyclidine-induced changes in synaptophysin and Arc gene expression in the mouse prefrontal cortex. Neurochem Int 57:756761. CrossRef Medline

Tseng HH, Bossong MG, Modinos G, Chen KM, McGuire P, Allen P (2015) A systematic review of multisensory cognitive-affective integration in schizophrenia. Neurosci Biobehav Rev 55:444-452. CrossRef Medline

Uylings HB, Groenewegen HJ, Kolb B (2003) Do rats have a prefrontal cortex? Behav Brain Res 146:3-17. CrossRef Medline

Van De Werd HJ, Uylings HB (2008) The rat orbital and agranular insular prefrontal cortical areas: a cytoarchitectonic and chemoarchitectonic study. Brain Struct Funct 212:387-401. CrossRef Medline

Wildeboer KM, Stevens KE (2008) Stimulation of the $\alpha 4 \beta 2$ nicotinic receptor by 5 -I A- 85380 improves auditory gating in DBA/2 mice. Brain Res 1224:29-36. CrossRef Medline

Williams LE, Light GA, Braff DL, Ramachandran VS (2010) Reduced multisensory integration in patients with schizophrenia on a target detection task. Neuropsychologia 48:3128-3136. CrossRef Medline

Winters BD, Reid JM (2010) A distributed cortical representation underlies crossmodal object recognition in rats. J Neurosci 30:6253-6261. CrossRef Medline

Zhang Y, Behrens MM, Lisman JE (2008) Prolonged exposure to NMDAR antagonist suppresses inhibitory synaptic transmission in prefrontal cortex. J Neurophysiol 100:959-965. CrossRef Medline 